\title{
Long-Term Changes in Water Quality and Productivity in the Patuxent River Estuary: 1985 to 2003
}

\author{
Jeremy M. Testa $\cdot$ W. Michael Kemp • \\ Walter R. Boynton • James D. Hagy III
}

Received: 25 January 2008 /Revised: 23 June 2008 / Accepted: 29 August 2008 /Published online: 18 September 2008

(C) Coastal and Estuarine Research Federation 2008

\begin{abstract}
We conducted a quantitative assessment of estuarine ecosystem responses to reduced phosphorus and nitrogen loading from sewage treatment facilities and to variability in freshwater flow and nonpoint nutrient inputs to the Patuxent River estuary. We analyzed a 19-year dataset of water quality conditions, nutrient loading, and climatic forcing for three estuarine regions and also computed monthly rates of net production of dissolved $\mathrm{O}_{2}$ and physical transport of dissolved inorganic nitrogen (DIN) and phosphorus (DIP) using a salt- and waterbalance model. Point-source loading of DIN and DIP to the estuary declined by $40-60 \%$ following upgrades to sewage treatment plants and correlated with parallel decreases in DIN and DIP concentrations throughout the Patuxent. Reduced point-source nutrient loading and concentration resulted in declines in phytoplankton chlorophyll- $a$ (chl- $a$ ) and light-saturated carbon fixation, as well as in bottomlayer $\mathrm{O}_{2}$ consumption for upper regions of the estuary. Despite significant reductions in seaward $\mathrm{N}$ transport from
\end{abstract}

J. M. Testa $(\bowtie) \cdot$ W. M. Kemp

Horn Point Laboratory, University of Maryland Center for Environmental Science,

P.O. Box 775, Cambridge, MD 21613, USA

e-mail: jtesta@hpl.umces.edu

\section{W. R. Boynton}

Chesapeake Biological Laboratory, University of Maryland Center for Environmental Science,

P.O. Box 38, Solomons, MD 20688, USA

J. D. Hagy III

US Environmental Protection Agency, National Health and Environmental Effects Research Laboratory,

Gulf Ecology Division,

1 Sabine Island Drive,

Gulf Breeze, FL 32561, USA the middle to lower estuary, chl- $a$, turbidity, and surfacelayer net $\mathrm{O}_{2}$ production increased in the lower estuary, especially during summer. This degradation of water quality in the lower estuary appears to be linked to a trend of increasing net inputs of DIN into the estuary from Chesapeake Bay and to above-average river flow during the mid-1990s. In addition, increased abundance of Mnemiopsis leidyi significantly reduced copepod abundance during summer from 1990 to 2002, which favored increases in chl$a$ and allowed a shift in total $\mathrm{N}$ partitioning from DIN to particulate organic nitrogen. These analyses illustrate (1) the value of long-term monitoring data, (2) the need for regional scale nutrient management that includes integrated estuarine systems, and (3) the potential water quality impacts of altered coastal food webs.

Keywords Eutrophication - Water quality - Patuxent River . Box model

\section{Introduction}

Effects of eutrophication are becoming increasingly evident in Chesapeake Bay (Kemp et al. 2005) and other coastal systems worldwide (Cloern 2001). Coastal eutrophication is often driven by elevated nutrient inputs via sewage discharge, agricultural runoff, and atmospheric deposition (Jickells 2005). Eutrophication can alter the structure and function of coastal systems, with responses including loss of submerged aquatic vegetation (Duarte 1995), decreased dissolved $\mathrm{O}_{2}$ concentrations (Diaz 2001), increased blooms of toxic algae (Paerl 1988), and shifts in food web structure (McClelland and Valiela 1998). Effective management of coastal systems requires improved scientific understanding of ecological responses to changes in nutrient inputs. 
Nutrient load reductions have been implemented in many coastal systems to improve water quality conditions (Conley et al. 2002; Kemp et al. 2005). Although eutrophication abatement has traditionally targeted reductions in phosphorus (P) for freshwater systems (e.g., Edmondson 1970; Schindler 1978; Gibson et al. 2000) and nitrogen $(\mathrm{N})$ for marine systems (Greening and Janicki 2006; Mallin et al. 2005), more recent restoration efforts in estuaries have emphasized needs for reductions in both $\mathrm{P}$ and N (Kemp et al. 2005; Paerl et al. 2006). Concerns about eutrophication and other ecological changes in estuaries throughout the world have led to ambitious water quality monitoring programs designed, in part, to evaluate the response to changes in nutrient loading (Cloern 2001). Previous studies have used monitoring data to measure the recovery of water quality (e.g., nutrients, chlorophyll- $a$ (chl-a), $\mathrm{O}_{2}$, turbidity) in coastal systems following nutrient load reduction (Smith et al. 1981; Carstensen et al. 2006). In some cases, however, monitoring data have revealed more complex changes that are attributed to interactions between climatic, anthropogenic, and ecological processes (Paerl et al. 2006).

Climatic variability also influences estuarine ecological processes. Fluctuations of freshwater inputs affect nutrient loads, water-column stratification, and residence times, all of which control water quality and may mask ecosystem responses to management (Howarth et al. 2000; Paerl et al. 2006). In many estuaries, high freshwater inputs increase nutrient loads and phytoplankton biomass, thereby causing increased turbidity and reduced bottom-water dissolved $\mathrm{O}_{2}$ (e.g., Boynton and Kemp 2000). On the other hand, elevated freshwater flow may reduce phytoplankton growth by inducing light limitation or reducing residence time (Cloern et al. 1983; Howarth et al. 2000). Understanding interactions between nutrient management and freshwater flow will help in developing effective strategies for water quality regulation in coastal waters.

In some instances, the control of phytoplankton growth in aquatic ecosystems can also be attributable to "topdown" effects where changes in abundance of phytoplankton grazers measurably affect phytoplankton production and biomass. Although top-down control has been displayed in lakes (e.g., Carpenter and Kitchell 1988; Jeppesen et al. 2005) and, to some extent, in estuaries (e.g., White and Roman 1992), it is unclear whether changes in zooplankton grazing could affect long-term variation in phytoplankton biomass. Studies on temporal trends in water quality need to consider the potential effects of grazing control, particularly when the duration of time series is sufficiently long ( $>10$ years) to capture these dynamics (e.g., Cloern et al. 2007).

In one major tributary of Chesapeake Bay, the Patuxent River estuary, point-source $\mathrm{P}$ and $\mathrm{N}$ loads decreased abruptly in 1986 and 1991, respectively (Lung and Bai 2003). Reductions in P loads began with a statewide ban on phosphate-based detergents in 1984, followed by subsequent upgrading of the sewage treatment facilities. Reductions in $\mathrm{N}$ loads from sewage treatment plants began in 1991 with the installation of biological nitrogen removal (BNR) systems. In recent decades, river flow into the Patuxent has recently been highly variable, with annual mean flows ranging from 10 to $34 \mathrm{~m}^{3} \mathrm{~s}^{-1}$ (Testa 2006). An integrated monitoring program has been in place since 1985 for the Patuxent, generating data on water quality, nutrient loads, freshwater inflows, and plankton abundance. Although recent studies have focused on specific aspects of ecological responses to nutrient load reductions in the Patuxent (Stankelis et al. 2003; Fisher et al. 2006), a comprehensive analysis of trends and changes in biological and chemical processes has been lacking. The purpose of this paper is to analyze a long-term water quality dataset for the Patuxent estuary and to relate these trends to changes in nutrient management, freshwater flow, and plankton community structure.

\section{Methods}

Study Site, Water Quality, and Biological Monitoring Data

The Patuxent River estuary is a tributary of Chesapeake Bay (Fig. 1). Two-layered circulation occurs for most of the year in the estuary, with a seaward-flowing surface layer and a landward-flowing bottom layer. The upper estuary (above $45 \mathrm{~km}$ ) is vertically well mixed. We compiled water quality measurements along the estuarine axis of the Patuxent (Fig. 1) from the Chesapeake Bay Monitoring Program (CBP 2005) for the period 1985 to 2003, including dissolved inorganic nitrogen (DIN; $\mathrm{NO}_{3}{ }^{-}+\mathrm{NO}_{2}{ }^{-}+\mathrm{NH}_{4}{ }^{+}$), dissolved inorganic phosphorous (DIP; $\mathrm{PO}_{4}{ }^{3-}$ ), total nitrogen $(\mathrm{TN})$, total phosphorus (TP), dissolved oxygen $\left(\mathrm{O}_{2}\right)$, chl- $a$, Secchi depth, and salinity. Water samples were obtained from a submersible pump and stored for later analysis. The methods used for chemical analysis undergo routine robust $\mathrm{QA} / \mathrm{QC}$ reviews (CBP 2005). We also examined trends in measurements of light-saturated carbon fixation $\left(\mu \mathrm{g} \mathrm{l}^{-1} \mathrm{~h}^{-1}\right)$ from 4-h incubations of triplicate bottles (CBP 2005).

We examined trends in the abundance of adult copepods, Acartia tonsa, and the ctenophore, Mnemiopsis leidyi. Zooplankton samples were obtained from the Bay-wide Chesapeake Bay Program Plankton Database (CBP 2005) at station LE1.1 in the Patuxent River (38.42512, -76.60163; NAD83). Samples were collected once a month from 1985 to 2002, but January and December cruises were terminated after 1991. The sampling protocol includes two 


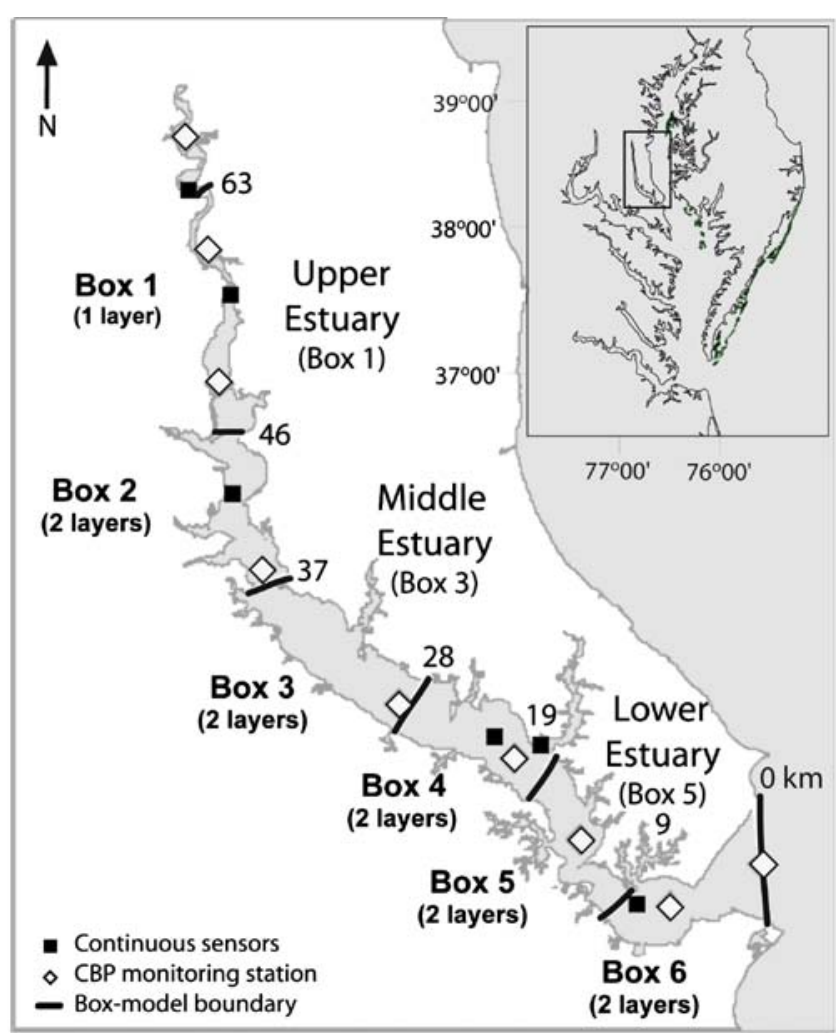

Fig. 1 Map of the Patuxent River estuary with Chesapeake Bay (inset), including box-model boundaries (Hagy et al. 2000), water quality monitoring stations, and the location of continuous water quality sensors (MD DNR 2005). Numbers at the right of box-model boundaries indicate distance from the mouth of the estuary $(\mathrm{km})$

stepped oblique tows with paired bongo nets through the entire water column (CBP 2005). One of the nets is used for abundance measurements of $A$. tonsa and M. leidyi.

\section{Computing Salt and Water Transport}

We computed the Patuxent estuary's time-dependent mean circulation using a box-modeling approach (Officer 1980) with monthly mean salinity (CBP 2005) and freshwater input data (USGS 2005; NOAA 2005). Streamflow was measured at a gauging station in Bowie, MD, USA (USGS 2005), which represented $39 \%$ of the watershed. Freshwater inputs from nongauged portions of the watershed were estimated as in Hagy et al. (2000). This approach calculates advective and diffusive exchanges of water and salt between adjacent control volumes (that are assumed to be well mixed) and across end-member boundaries using the solution to non-steady-state equations balancing salt and water inputs, outputs, and storage changes. Stratified estuarine regions are represented by surface and bottom layers that capture the essential features of two-layered estuarine circulation and the box model used in this analysis calculates advection and mixing between 11 volumes in the Patuxent estuary (six surface, five bottom boxes; Hagy et al. 2000). The salt and water balances for the surface layer of box $m$ in the two-layer scheme are

$$
\begin{aligned}
V_{m} \frac{d s_{m}}{d t}= & Q_{m-1} s_{m-1}+Q_{v m} s_{m}^{\prime}-Q_{m} s_{m} \\
& +E_{v m}\left(s_{m}^{\prime}-s_{m}\right) \\
& +\left[E_{m-1, m}\left(s_{m-1}-s_{m}\right)+E_{m, m+1}\left(s_{m+1}-s_{m}\right)\right]
\end{aligned}
$$

$\frac{d V_{m}^{\prime}}{d t}=0=Q_{m}-\left(Q_{m-1}+Q_{v m}+Q_{f m}\right)$

where $V_{m}$ is the volume of the box; $Q_{f m}$ is the freshwater input directly into the box; $Q_{m}$ and $Q_{m-1}$ are the advective water transports to the seaward box and from the landward box; $Q_{v m}$ is the vertical advective input into the box; $E_{v m}$ is the vertical diffusive exchange; $E_{m-1, m}$ and $E_{m, m+1}$ are the diffusive exchanges with the landward box and with the seaward box, respectively (Fig. 2); $s_{m}$ and $s_{m}^{\prime}$ are the salinities in the upper- and bottom-layer boxes, and $s_{m-1}$ and $s_{m+1}$ are the salinities in the landward and seaward boxes. The left hand side of Eq. 1 is the time rate of change of salinity for each month (calculated from the time series of

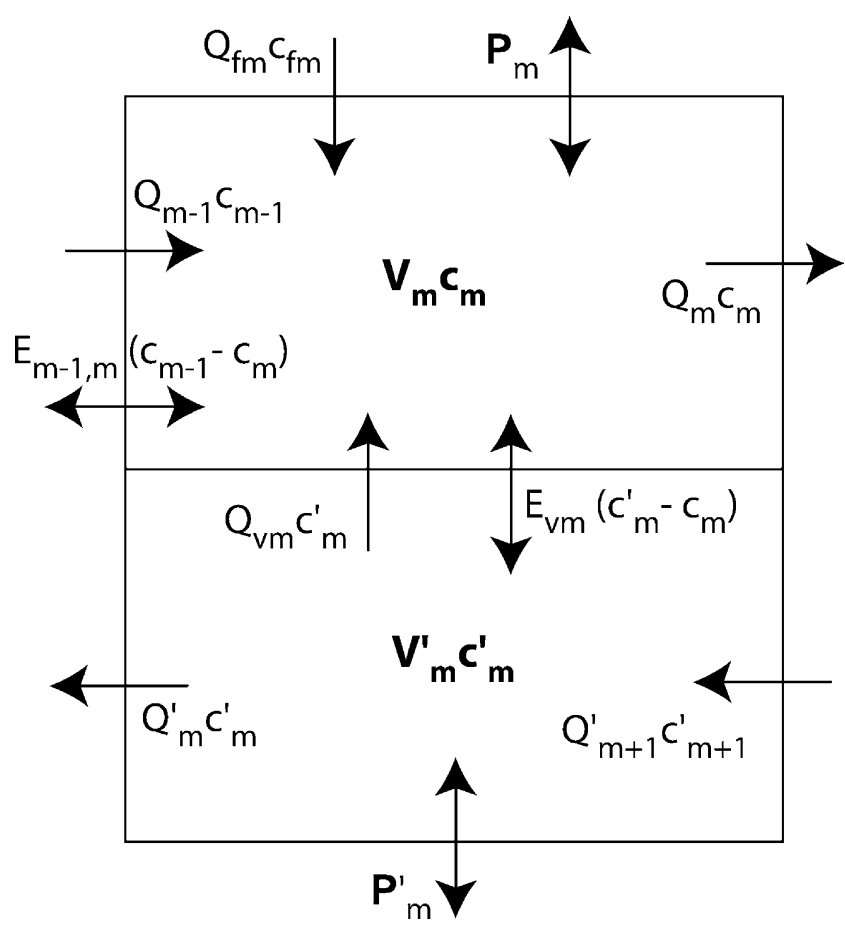

Fig. 2 Generalized depiction of two-layer nonconservative box-model for boxes 2-6. The nonadvective exchange, $E_{m, m-1}\left(c_{m}-c_{m-1}\right)$, is a term for the calculation in box 2 only. Atmospheric inputs are included ( $\left.Q_{\mathrm{fm}} c_{\mathrm{fm}}\right)$, though the nonconservative flux of DIN is the only rate where atmospheric inputs are included. Descriptions of the terms are located in the "Methods" section 
mean salinity), while the left hand side of Eq. 2 (volume change) is assumed to be zero. We assumed that $E_{m, m-1}=0$ for $m \neq 2, E_{m, m+1}=0$ for $m \neq 1$, and $E_{v m}=0$ and $Q_{v m}=0$ for $m=1$ (Hagy 1996). The salt and water balances (Eqs. 3 and 4) for the bottom layer of box $m$ in the two-layer scheme are below

$$
\begin{aligned}
V_{m}^{\prime} \frac{d s_{m}^{\prime}}{d t}= & Q_{m+1}^{\prime} s_{m+1}^{\prime}-Q_{v m}^{\prime} s_{m}^{\prime}-Q_{m}^{\prime} s_{m}^{\prime} \\
& -E_{v m}\left(s_{m}^{\prime}-s_{m}\right)
\end{aligned}
$$

$\frac{d V^{\prime} m}{d t}=0=Q_{m}^{\prime}+Q_{v m}-Q_{m+1}^{\prime}$

where $Q_{m}^{\prime}$ and $Q_{m+1}^{\prime}$ are the advective transports to the landward box and from the seaward box and $s_{m+1}^{\prime}$ is the salinity of the seaward box in the bottom layer.

\section{Nutrient Transport and Production Rates}

We computed monthly net rates of physical transport and biogeochemical production of nonconservative constituents (e.g., DIN, $\mathrm{O}_{2}$ ) for six regions of the Patuxent River estuary from 1985 to 2003. Physical transport rates for these constituents were computed by multiplying solute concentrations by the advective $\left(Q_{m}\right)$ and nonadvective fluxes $\left(E_{m}\right)$ for each box and month. Rates were calculated for DIN, DIP, and dissolved $\mathrm{O}_{2}$. Monthly means were computed for each constituent and box (and for seaward and landward boundary conditions) using water quality monitoring data (Fig. 1). A simple linear spatial interpolation scheme was used to calculate mean concentrations within a grid of 477 cells spaced at $1-\mathrm{m}$ vertical intervals, $1.85-\mathrm{km}$ horizontal intervals, and spanning the width and length of the estuary for each sampling date (Hagy et al. 2000). Net production rates $\left(P_{m}\right.$ or $P_{m}^{\prime}=$ production-consumption) were computed for each box from the advective $\left(Q_{m}\right)$ and diffusive $\left(E_{m}\right)$ transport rates by rearranging the mass-balance equation in each box (Hagy 1996). The equations are similar in form to the salt balance (Eqs. 1 and 2) except salinity is replaced with the water quality constituent and the net production term is added. For the surface layer of box $m$ in the twolayer scheme, the mass-balance equation is

$$
\begin{aligned}
V_{m} \frac{d c_{m}}{d t}= & Q_{m-1} c_{m-1}+Q_{v m} c_{m}^{\prime}+E_{v m}\left(c_{m}^{\prime}-c_{m}\right) \\
& -Q_{m} c_{m}+P_{m}
\end{aligned}
$$

which can be rearranged to calculate $P_{m}$

$$
\begin{aligned}
P_{m}= & V_{m} \frac{d c_{m}}{d t}-Q_{m-1} c_{m-1}-Q_{v m} c_{m}^{\prime}-E_{v m}\left(c_{m}^{\prime}-c_{m}\right) \\
& +Q_{m} c_{m}
\end{aligned}
$$

Similarly, for the bottom layer of box $m$, the mass-balance expression is

$$
\begin{aligned}
V_{m}^{\prime} \frac{d c_{m}^{\prime}}{d t}= & Q_{m+1}^{\prime} c_{m+1}^{\prime}-Q_{v m} c_{m}^{\prime}-Q_{m} c_{m}^{\prime} \\
& -E_{v m}\left(c_{m}^{\prime}-c_{m}\right)+P_{m}^{\prime}
\end{aligned}
$$

which can be rearranged to calculate bottom-layer net production, $P_{m}^{\prime}$

$$
\begin{aligned}
P_{m}^{\prime}= & V_{m}^{\prime} \frac{d c_{m}^{\prime}}{d t}-Q_{m+1}^{\prime} c_{m+1}^{\prime}+Q_{v m} c_{m}^{\prime}+Q_{m}^{\prime} c_{m}^{\prime} \\
& +E_{v m}\left(c_{m}^{\prime}-c_{m}\right)
\end{aligned}
$$

where $c$ is the concentration of the nonconservative constituent, and $P_{m}$ and $P_{m}^{\prime}$ are net production (or consumption) rates in the surface and bottom layers, respectively (Fig. 2), calculated per unit area or volume using geometry data for each box. Because the water in both surface- and bottom-layer boxes is in contact with sediments, we consider $P_{m}$ and $P_{m}^{\prime}$ to represent the net behavior of the water column and sediments. Input terms for wet atmospheric deposition of DIN were added to massbalance equations of surface-layer boxes and deposition rates were calculated using data for precipitation volume and concentrations of DIN (NADP 2005). Nonpoint DIN and DIP inputs to surface boxes from ungauged portions of the watershed were found to be small components of the nutrient balances (Testa and Kemp 2008) and were excluded from box-model computations.

Computing net production of dissolved $\mathrm{O}_{2}$ in surface layers required adjustments to observed $\mathrm{O}_{2}$ concentrations both for time of sampling and for air-water exchange. The first step was to adjust observed $\mathrm{O}_{2}$ concentrations at a particular time of day to the equivalent daily mean $\mathrm{O}_{2}$ value for that day. This was accomplished using measurements of diel variations in $\mathrm{O}_{2}$ concentrations (15-min intervals) observed at nearby moored-sensor stations (Fig. 1). Hourly mean $\mathrm{O}_{2}$ values (as percent saturation) were calculated for each month of the year at six moored-sensor stations (MD DNR 2005; ACT 2005; Fig. 1) that span the estuarine axis. We calculated a "diel correction" coefficient for each hour of the day in each month at each station as the ratio of the daily mean $\mathrm{O}_{2}$ concentration to the hourly mean $\mathrm{O}_{2}$ concentration for the sampling hour that day.

We corrected monthly calculations of net $\mathrm{O}_{2}$ production in surface boxes for air-water gas exchange $F_{\mathrm{A}-\mathrm{O}_{2}}$ using $\mathrm{O}_{2}$ values measured in the top $0.5 \mathrm{~m}$ of the water column using the following equation: $F_{\mathrm{A}-\mathrm{O}_{2}}=\alpha\left(1-\left[C_{\mathrm{O}_{2}} / C_{\mathrm{O}_{2} \mathrm{~S}}\right]\right)$ Here, $\alpha$ is the air-water exchange coefficient $\left(\mathrm{mmol} \mathrm{O}_{2} \mathrm{~m}^{-2}\right.$ day $\left.{ }^{-1}\right) ; C_{\mathrm{O}_{2}}$ is the adjusted daily mean $\mathrm{O}_{2}$ concentration at $0.5-\mathrm{m}$ depth $\left(\mathrm{mmol} \mathrm{m}{ }^{-3}\right) ; C_{\mathrm{O}_{2} S}$ is the $\mathrm{O}_{2}$ saturation value $\left(\mathrm{mmol} \mathrm{m}{ }^{-3}\right)$. Based on published relationships with wind speed (e.g., Marino and Howarth 1993) and monthly mean 
wind data observed at the nearby airport, we estimated a mean value for $\alpha$ of $3.75 \times 10^{2} \mathrm{mmol} \mathrm{m}^{-2}$ day $^{-1}\left(0.5 \mathrm{~g} \mathrm{~m}^{-2}\right.$ $\mathrm{h}^{-1}$ ) that was used for all months (Caffrey 2003). Analyses of wind data suggested that there were significant variations in wind velocity on daily to weekly scales, but there were no significant seasonal trends. Sensitivity analysis showed that variation in $\alpha$ of $\pm 50 \%$ resulted in small changes in net $\mathrm{O}_{2}$ production $(5-10 \%$ in the middle and lower estuary (boxes $3-6)$ and $5-15 \%$ in the upper estuary (boxes 1-2)).

\section{Hypoxia}

To obtain an integrated measure of interannual variations in the severity, spatial extent, and duration of hypoxia in the Patuxent estuary, we calculated hypoxic volume by summing the volume of the 477 interpolated cells (see above) with a dissolved $\mathrm{O}_{2}$ concentration less than $62.5 \mu \mathrm{M}$ for each sampling date from 1985 to 2003. The integrated area under the time series of hypoxic volume (with linear interpolation between sampling dates) for each year is equivalent to hypoxic volume days, a time-volumeintegrated value that represents hypoxia $\left(\mathrm{m}^{3}\right.$ day year $\left.{ }^{-1}\right)$.

\section{Nutrient Loading}

We assembled data for monthly TN, DIN, TP, and DIP loads to the estuary from a stream gage representing $39 \%$ of the watershed area (Bowie, MD, USA; USGS 2005) for 1985 to 2003. Nutrient loads were modeled based on daily mean streamflow and submonthly nutrient samples (Langland et al. 2006). Inputs of TN, TP, and water from sewage treatment plants were obtained from the Chesapeake Bay Program nutrient input monitoring program from 1985 to 2003 (CBP 2005). To account for changes in nutrient loads from nongauged portions of the watershed, we obtained estimates of annual, nonpoint TN, DIN, TP, and DIP loads to the Patuxent river estuary from output of the Chesapeake Bay Watershed Model from 1985 to 1997 (Linker et al. 1996, 2000). This model uses the Hydrological Simulation Program-FORTRAN model to compute nutrient loads to receiving waters from both a hydrologic nonpoint source submodel (runoff and subsurface flows) and a river submodel. We used the hydrologic submodel loads.

\section{Statistical Analyses}

We tested the responses of water quality and box-modelcomputed production rates to nutrient load reductions using two different approaches. First, we examined temporal trends in the time-series data from 1985 to 2003 using two different types of trend analysis. Simple linear regression (GLM procedure; SAS v9.1) was used to evaluate the time trends (e.g., $r^{2}$ and slope $\pm \mathrm{SE}$ ) in annual and summer means of chl- $a$, Secchi depth, DIN and DIP concentrations, and net $\mathrm{O}_{2}$ production $(n=19)$. We analyzed summer trends to help deduce dynamics specific to this highly productive season. To provide a nonparametric test to compare with the regressions, we also performed seasonal Kendall tests to examine trends using the monthly means of the water quality variables. For the seasonal Kendall tests, tau was calculated as the weighted average of seasonal estimates and slope was calculated with the modification of Hirsch et al. of the Thiel/Sen Estimator (Millard 2002). All trend tests were performed on a base dataset of monthly means of chl$a$, DIN, and DIP $(n=228)$ from 1985 to 2003 in each surface-layer box (Fig. 1) for comparison with computed net $\mathrm{O}_{2}$ production rates. For Secchi depth, trends were computed for the monthly means of measurements $(n=228)$ made at monitoring stations within each box.

Secondly, to test for significant changes in water quality after sewage treatment upgrades for nitrogen, Wilcoxon rank sum tests (exact test) were performed on both annual and summer (May-August) means for the same variables as the trend tests (SAS v9.1). For comparisons of means for periods before and after upgrades for nitrogen removal at sewage treatment plants, data were parsed into two groups; pre-BNR (1985 to $1990, n=6)$ and post-BNR (1991 to 2003, $n=13$ ). Wilcoxon rank sum tests were also performed on box-model-computed June-August surface- and bottomlayer net $\mathrm{O}_{2}$ production rates in boxes 2-6 and MayAugust and annual surface-layer seaward DIN transport rates in boxes $3-5$.

Because of the large number of tests performed, there is increased possibility of type I errors. Although we do not present an overall scheme for limiting the type I error rate, we focus our discussion on highly significant results (e.g., $p<0.01)$ and coherent patterns in the data, which emerge from several significant tests.

\section{Results}

Nutrient Loading Trends

Point-source discharges of TN declined by up to $50 \%$ after the implementation of BNR at sewage treatment facilities beginning in 1991 (Fig. 3). Similarly, point-source discharge of TP declined sharply beginning in 1986 ( $>50 \%$ decline) after the statewide ban on phosphate use in detergents and sewage treatment plant upgrades. Winter discharges of TN from sewage plants remained high due to seasonally varying treatment protocols (Fig. 3). In contrast, discharges of water from all sewage treatment facilities in the watershed increased steadily from 1985 to 2003, as population increased in the watershed (Fig. 3; D'Elia et al. 2003). In the upper estuary, point-source loads comprised 

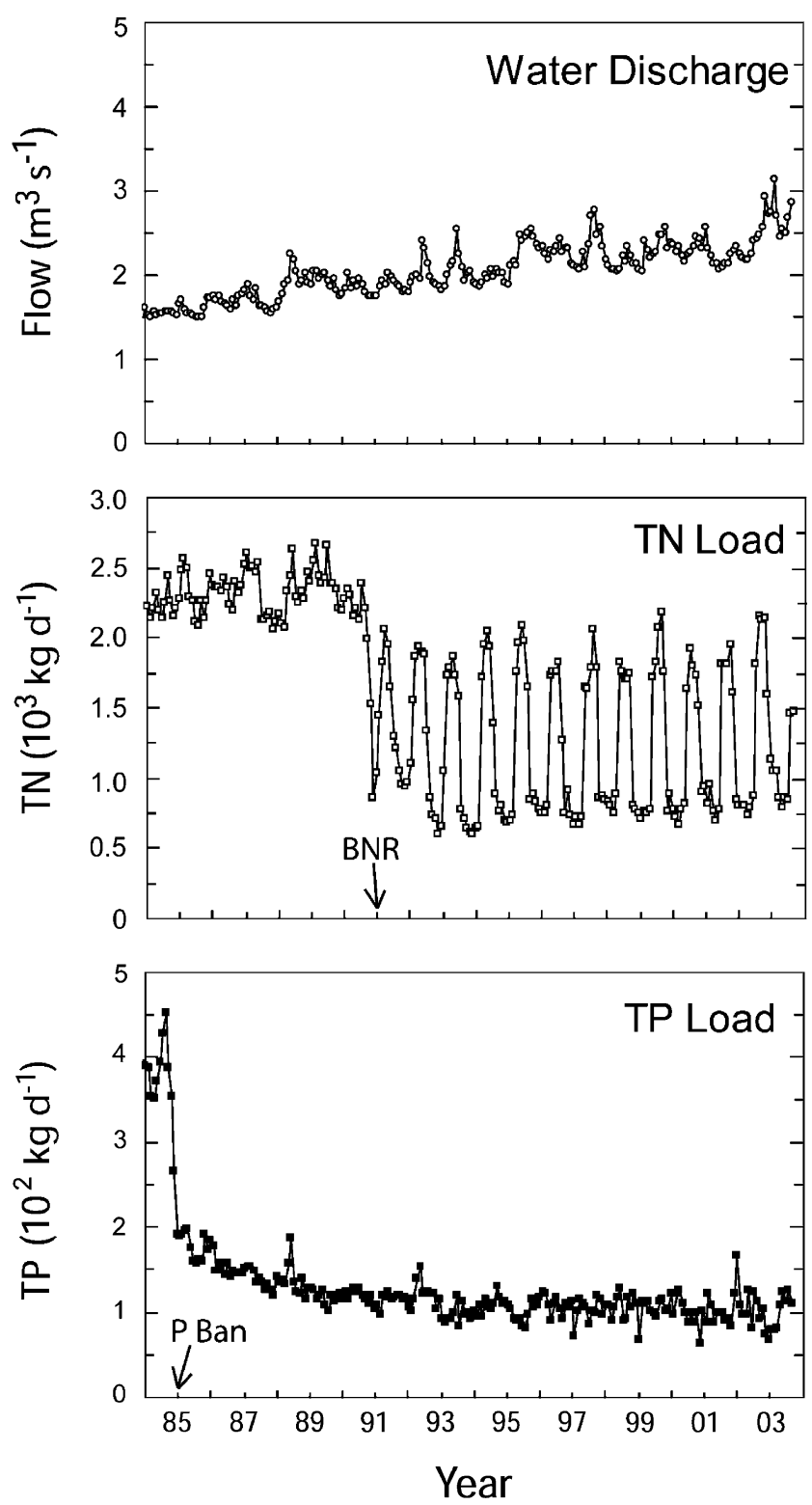

Fig. 3 Mean monthly water discharge and inputs of total nitrogen $(T N)$, and total phosphorus $(T P)$ from all sewage treatment facilities in the Patuxent River watershed from 1985 to 2003. BNR indicates the onset of installations of biological nitrogen removal systems in sewage treatment plants in the watershed, while the introduction of phosphorus removal is indicated by " $P$ Ban." Data are from the Chesapeake Bay Program's Point-Source Nutrient Database (CBP 2005)

$50-60 \%$ of TN loads before 1990 but afterward comprised only $20-30 \%$.

Following sewage treatment upgrades, trends in TN and TP concentrations showed significant declines $(p<0.01)$ in the nontidal freshwater region of the river through 2002 (Fig. 4), though in the very wet year of 2003 , concentrations were high. The concentration declines led to reductions of $100 \mathrm{~kg} \mathrm{~N}$ per day and $116 \mathrm{~kg} \mathrm{P}$ per day for in-stream loads from this section of the river (Fig. 4). Annual mean box-model-computed rates of DIN transport
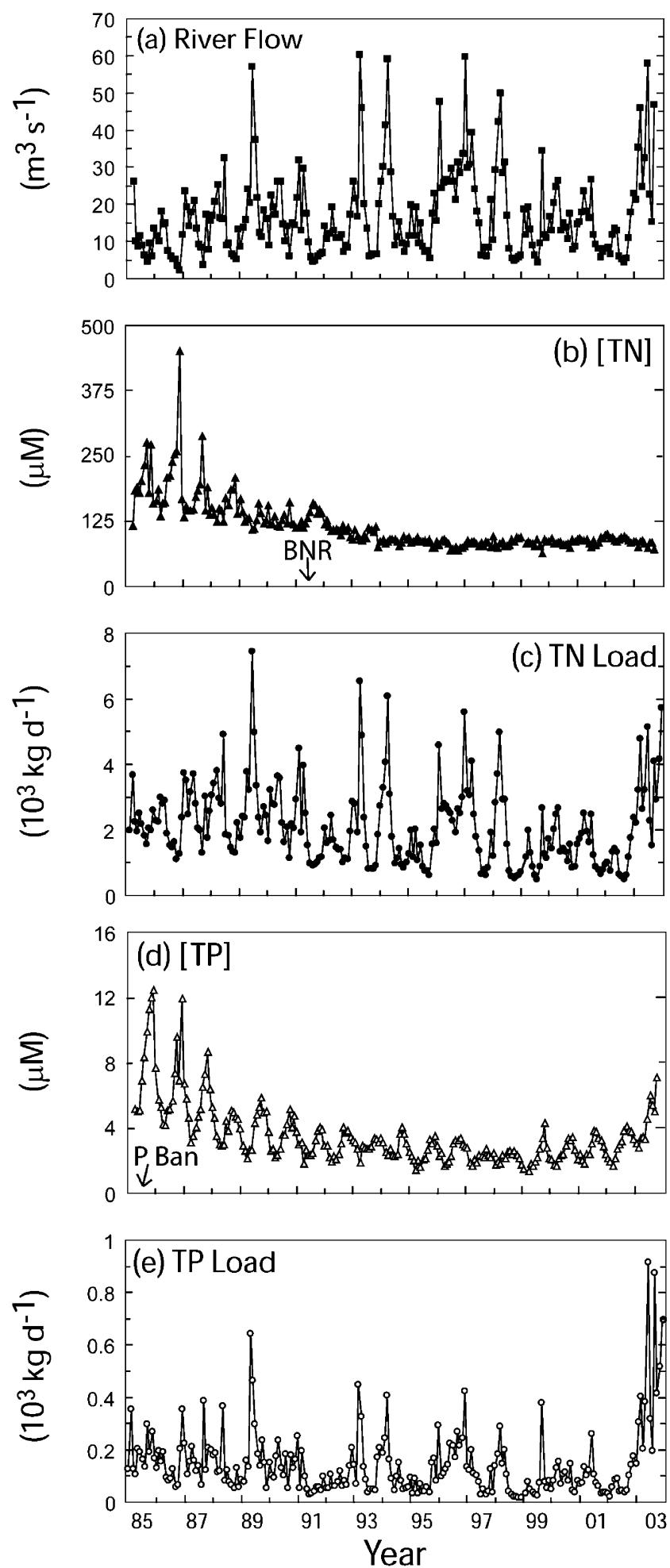

Fig. 4 Time series (1985 to 2003) of mean monthly river discharge (a), total nitrogen concentrations (b) and loads (c), and total phosphorus concentrations (d) and loads (e) at the USGS gauging station at Bowie, MD, USA (USGS 2005), which is located just upstream of the tidally influenced portion of the river 
to the middle (box 3 to box 4) and lower (box 4 to box 5) estuary both decreased by $20 \%$ after 1990 , but the reductions were insignificant (Wilcoxon rank sum test, $p>$ 0.1). After 1990, summer mean rates of DIN transport to the middle (box 3 to box 4) and lower (box 4 to box 5) estuary both decreased by $40 \%$ and reductions in DIN transport from box 3 to 4 and from box 4 to 5 in summer were significant (Wilcoxon rank sum test, $p<0.05$ ). River flow has been higher on average during the 13 years after $1990\left(19.2 \pm 2.3 \mathrm{~m}^{3} \mathrm{~s}^{-1}(\mathrm{SE})\right)$ than in the mid to late $1980 \mathrm{~s}$ $\left(14.4 \pm 1.8 \mathrm{~m}^{3} \mathrm{~s}^{-1}(\mathrm{SE})\right)$ when nutrient loads were higher (Fig. 4). TN loads from nonpoint sources from the watershed above Benedict, MD, USA were elevated from 1990 to $1997\left(3.0 \pm 0.37\right.$ (SE) $\left.10^{3} \mathrm{~kg} \mathrm{day}^{-1}\right)$ relative to the period 1985 to $1989\left(2.0 \pm 0.26(\mathrm{SE}) 10^{3} \mathrm{~kg} \mathrm{day}^{-1}\right)$.

\section{Water Quality Trends}

Temporal changes in water quality are reported for three estuarine regions (Fig. 1): the upper (box 1), the middle (box 3), and the lower estuary (box 5). Trends from 1985 to 2003 reveal significant declines (Table 1) in annual mean DIN concentration throughout the estuary with reductions in DIN concentration of 30-50\% (Fig. 5). DIP concentrations also declined significantly in all regions of the estuary after 1986, following the ban on phosphate detergents and sewage treatment upgrades (Table 1, Fig. 5). The seasonal Kendall test and Wilcoxon rank sum test also indicated significant declines in DIN and DIP concentrations. Although annual mean DIN concentrations were elevated to pre-1990 levels in all estuarine regions during the high-river-flow years of the mid-1990s, DIN was not significantly correlated with river flow in any estuarine region $\left(r^{2}=0.1-0.2, p>0.1\right)$. DIP was also not correlated with river flow in any estuarine region $\left(r^{2}<0.15, p>0.1\right)$. We found a significant correlation between total sewage nitrogen load and DIN concentration in the upper estuary $\left(r^{2}=0.69, p<0.01\right)$ but not in other regions. Relative declines for summer (May to August) DIN and DIP concentrations were larger than for the annual means, except for DIN in the upper estuary (Tables 1 and 2, Fig. 5).

Declines in summer mean total dissolved nitrogen (TDN) concentrations were significant in middle $\left(r^{2}=0.42\right.$, $p<0.01$, slope $=-0.83 \mu \mathrm{M}$ year $\left.{ }^{-1}\right)$ and lower estuary $\left(r^{2}=\right.$ $0.38, p<0.01,-0.59 \mu \mathrm{M}$ year $^{-1}$ ) and closely followed trends in DIN from 1985 to 2003 (Fig. 6). Conversely, declining trends in summer mean TN concentrations were significant in the upper estuary $\left(r^{2}=0.46, p<0.01\right.$, $-1.68 \mu \mathrm{M}$ year $^{-1}$ ), but there were no apparent changes in the middle and lower estuary (Fig. 6). Summer mean particulate organic nitrogen $(\mathrm{PON}=\mathrm{TN}-\mathrm{TDN})$ decreased significantly in the upper estuary $\left(r^{2}=0.39, p<0.01\right.$, $-0.94 \mu \mathrm{M}$ year $\left.^{-1}\right)$ but increased $\left(r^{2}=0.42, p<0.01\right.$, $+0.75 \mu \mathrm{M}$ year $^{-1}$ ) in the lower estuary.

In the upper estuary, annual mean planktonic chl- $a$ concentrations were generally lower after 1990 (i.e., postBNR) than before, but trend tests and Wilcoxon rank sum tests for both annual and summer means indicated no

Table 1 Statistical results for (a) linear regression (trend tests), (b) pre- and post-BNR means, and (c) Wilcoxon rank sum tests on annual means of 1985 to 2003 water quality data for the upper (box 1), middle (box 3), and lower (box 5) Patuxent estuary

\begin{tabular}{|c|c|c|c|c|c|c|c|}
\hline \multirow[t]{2}{*}{ Variable } & \multirow[t]{2}{*}{ Region } & \multicolumn{3}{|c|}{ Trend statistics } & \multicolumn{2}{|l|}{ Means $( \pm \mathrm{SE})$} & \multirow{2}{*}{$\begin{array}{l}\text { Wilcoxor } \\
p \text { value }\end{array}$} \\
\hline & & $r^{2}$ & Slope $( \pm \mathrm{SE})$ & $p$ value & Pre-BNR & Post-BNR & \\
\hline \multirow[t]{3}{*}{ DIN } & Upper & 0.53 & $-1.35(0.29)$ & $<0.01 *$ & $64.01(1.13)$ & $45.82(2.85)$ & $<0.01^{*}$ \\
\hline & Middle & 0.38 & $-0.71(0.21)$ & $<0.01^{*}$ & $17.45(0.53)$ & $10.44(1.99)$ & $0.02 *$ \\
\hline & Lower & 0.29 & $-0.50(0.14)$ & $0.02 *$ & $12.98(1.13)$ & $8.14(1.70)$ & $0.04 *$ \\
\hline \multirow[t]{3}{*}{ DIP } & Upper & 0.40 & $-0.02(0.003)$ & $<0.01^{*}$ & $1.35(0.08)$ & $1.15(0.03\}$ & $0.02 *$ \\
\hline & Middle & 0.58 & $-0.04(0.006)$ & $<0.01 *$ & $1.06(0.10)$ & $0.71(0.04)$ & $<0.01^{*}$ \\
\hline & Lower & 0.48 & $-0.02(0.003)$ & $<0.01 *$ & $0.44(0.06)$ & $0.26(0.13)$ & $<0.01^{*}$ \\
\hline \multirow[t]{3}{*}{ Chl- $a$} & Upper & 0.002 & $-0.02(0.13)$ & 0.87 & $16.56(1.27$ & $16.07(0.97)$ & 0.38 \\
\hline & Middle & 0.08 & $0.37(0.26)$ & 0.23 & $16.82(2.15)$ & $17.35(1.86)$ & 0.45 \\
\hline & Lower & 0.18 & $0.35(0.17)$ & 0.06 & $10.65(1.21)$ & $12.29(1.36)$ & 0.32 \\
\hline \multirow[t]{3}{*}{$Z_{\mathrm{SD}}$} & Upper & 0.19 & $-0.005(0.002)$ & 0.06 & $0.43(0.03)$ & $0.37(0.02)$ & 0.26 \\
\hline & Middle & 0.09 & $-0.005(0.004)$ & 0.21 & $1.07(0.04)$ & $1.02(0.03)$ & 0.30 \\
\hline & Lower & 0.26 & $-0.020(0.007)$ & $0.03 *$ & $1.53(0.06)$ & $1.38(0.06)$ & 0.05 \\
\hline \multirow[t]{3}{*}{ Net $\mathrm{O}_{2}$ production } & Upper & 0.02 & $-0.11(0.46)$ & 0.55 & $-3.93(1.82)$ & $-0.14(3.41)$ & 0.36 \\
\hline & Middle & 0.06 & $0.16(0.15)$ & 0.30 & $13.11(2.84)$ & $15.29(1.88)$ & 0.15 \\
\hline & Lower & 0.15 & $0.20(0.09)$ & 0.10 & $5.97(1.46)$ & 8.35 (1.09) & 0.22 \\
\hline
\end{tabular}

$\mathrm{Z}_{\mathrm{SD}}$ is Secchi depth and $n=19$ for all tests.

$* p<0.05$ 

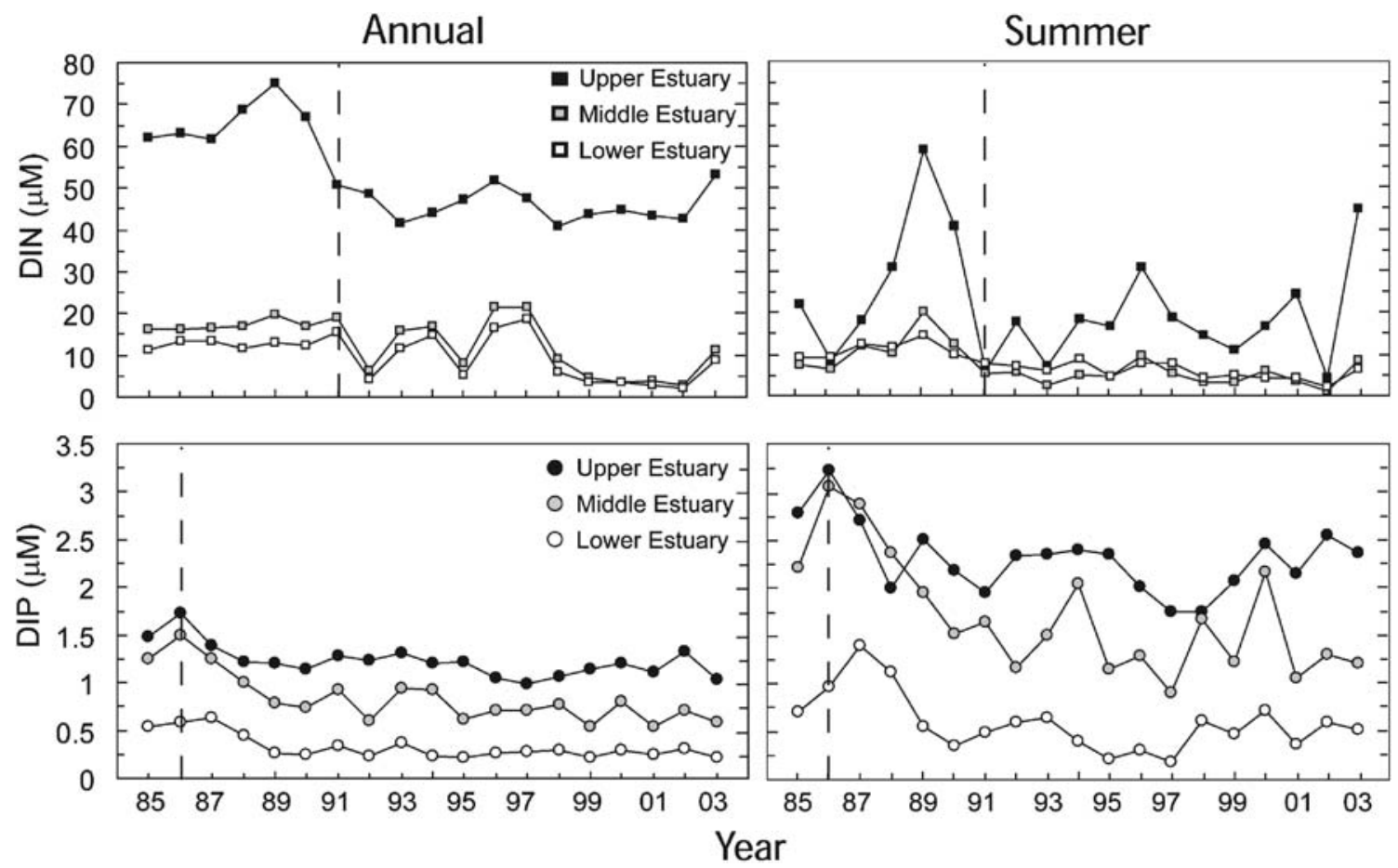

Fig. 5 Time series (1985 to 2003) of annual mean DIN (top left panel) and DIP (bottom left panel) concentrations and summer mean (May to August) DIN (top right panel) and DIP (bottom right panel) concentrations in the upper (box 1), middle (box 3), and lower (box 5)

significant changes from 1985 to 2003 (Table 1, Fig. 7). In contrast, chl- $a$ exhibited significant increasing trends in the middle and lower estuary based on the seasonal Kendall test $(p<0.05)$, and linear regression yielded a positive trend regions of the Patuxent River estuary. Data are mean concentrations in surface-layer boxes. Vertical dashed lines indicate the initiation of phosphorus and nitrogen removal at sewage plants

with a $p=0.06$ in the lower estuary (Table 1). Summer mean values for chl- $a$ exhibited significant $(p<0.05)$ positive trends in the middle and lower estuary from 1985 to 2003 and post-BNR chl- $a$ was significantly higher than pre-BNR

Table 2 Statistical results for (a) linear regression (trend tests), (b) pre- and post-BNR means, and (c) Wilcoxon rank sum tests on May-August means of 1985 to 2003 water quality data for the upper (box 1), middle (box 3), and lower (box 5) Patuxent estuary

\begin{tabular}{|c|c|c|c|c|c|c|c|}
\hline \multirow[t]{2}{*}{ Variable } & \multirow[t]{2}{*}{ Region } & \multicolumn{3}{|c|}{ Trend statistics } & \multicolumn{2}{|l|}{ Means $( \pm \mathrm{SE})$} & \multirow{2}{*}{$\begin{array}{l}\text { Wilcoxor } \\
p \text { value }\end{array}$} \\
\hline & & $r^{2}$ & Slope $( \pm \mathrm{SE})$ & $p$ value & Pre-BNR & Post-BNR & \\
\hline \multirow[t]{3}{*}{ DIN } & Upper & 0.01 & $-0.50(0.50)$ & 0.31 & $26.36(7.06)$ & $18.81(3.11)$ & 0.24 \\
\hline & Middle & 0.24 & $-0.39(0.16)$ & $0.03^{*}$ & $10.45(1.91)$ & $4.88(0.70)$ & $<0.01 *$ \\
\hline & Lower & 0.61 & $-0.44(0.10)$ & $<0.01^{*}$ & $10.46(0.89)$ & $5.69(0.56)$ & $<0.01 *$ \\
\hline \multirow[t]{3}{*}{ DIP } & Upper & 0.28 & $-0.02(0.006)$ & $0.02 *$ & $1.77(0.12)$ & $1.58(0.05)$ & 0.13 \\
\hline & Middle & 0.34 & $-0.05(0.010)$ & $<0.01^{*}$ & $1.59(0.16)$ & $0.99(0.08)$ & $<0.01^{*}$ \\
\hline & Lower & 0.25 & $-0.02(0.006)$ & $0.04 *$ & $0.57(0.10)$ & $0.34(0.04)$ & $0.04 *$ \\
\hline \multirow[t]{3}{*}{ Chl- $a$} & Upper & 0.03 & $-0.30(0.18)$ & 0.11 & $21.49(2.59)$ & $19.97(1.26)$ & 0.15 \\
\hline & Middle & 0.21 & $0.53(0.26)$ & $0.04 *$ & $11.74(2.02)$ & $16.54(1.94)$ & 0.05 \\
\hline & Lower & 0.35 & $0.72(0.26)$ & $0.01 *$ & $7.63(0.95)$ & $15.77(3.14)$ & $<0.01^{*}$ \\
\hline \multirow[t]{3}{*}{$Z_{\mathrm{SD}}$} & Upper & 0.11 & $-0.01(0.003)$ & 0.16 & $0.43(0.04)$ & $0.39(0.02)$ & 0.19 \\
\hline & Middle & 0.34 & $-0.01(0.004)$ & $0.02 *$ & $0.94(0.03)$ & $0.85(0.03)$ & $0.03^{*}$ \\
\hline & Lower & 0.58 & $-0.03(0.006)$ & $<0.01^{*}$ & $1.46(0.05)$ & $1.12(0.02)$ & $<0.01^{*}$ \\
\hline \multirow[t]{3}{*}{ Net $\mathrm{O}_{2}$ production } & Upper & 0.07 & $-0.79(0.56)$ & 0.17 & $-41.07(2.85)$ & $-47.50(4.54)$ & 0.19 \\
\hline & Middle & 0.17 & $0.42(0.36)$ & 0.25 & $4.66(4.18)$ & $14.87(1.65)$ & $<0.01^{*}$ \\
\hline & Lower & 0.14 & $0.34(0.25)$ & 0.19 & $4.40(1.23)$ & $9.48(1.51)$ & $0.02 *$ \\
\hline
\end{tabular}

$Z_{\mathrm{SD}}$ is Secchi depth and $n=19$ for all tests.

$* p<0.05$ 


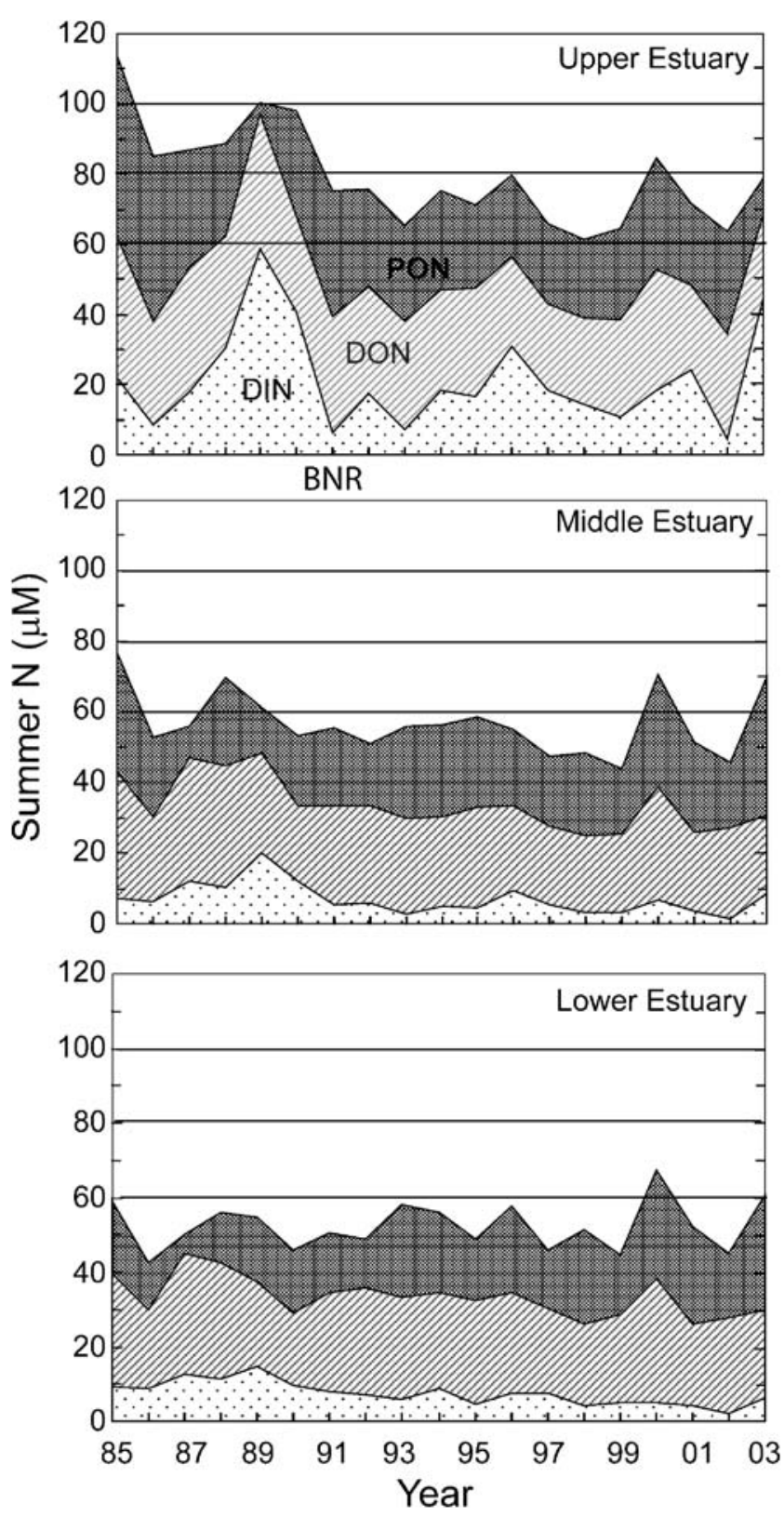

Fig. 6 Time series (1985 to 2003) of summer (May to August) mean total nitrogen (top line), total dissolved nitrogen (middle line), and dissolved inorganic nitrogen (DIN, bottom line) concentrations in the upper (box 1), middle (box 3), and lower (box 5) regions of the Patuxent River estuary. The area between the TN and TDN lines is particulate organic nitrogen $(P O N)$ and the area between the TDN and DIN lines is dissolved organic nitrogen $(D O N)$. Reference lines are located at $\mathrm{N}$ concentrations of 60,80 , and $100 \mu \mathrm{M}$

values (Table 2). On an annual scale, chl- $a$ was significantly correlated with river flow in the middle and lower estuary $\left(r^{2}=0.35,0.53\right.$, respectively, $\left.p<0.01\right)$ but not in the upper estuary. Trends in annual and summer mean values for Secchi depth showed significant decreases in the lower estuary from 1985 to 2003, corresponding with a significant reduction in mean Secchi depth (Tables 1 and 2) and a trend of increasing chl- $a$ (Fig. 7).
Net $\mathrm{O}_{2}$ Production

There were no significant linear trends in annual or summer mean surface-layer net $\mathrm{O}_{2}$ production from 1985 to 2003 (Tables 1 and 2), although we found significant negative trends in annual mean light-saturated carbon fixation for the tidal fresh $\left(r^{2}=0.35, p<0.05,-11.5 \mu \mathrm{g}^{-1} \mathrm{~h}^{-1}\right.$ year $\left.^{-1}\right)$ and oligohaline $\left(r^{2}=0.33, p<0.05,-4.7 \mu \mathrm{g} \mathrm{l}^{-1} \mathrm{~h}^{-1}\right.$ year $\left.^{-1}\right)$ regions. Summer (May to August) mean net $\mathrm{O}_{2}$ production in the surface layer was significantly higher after 1990 (post-BNR) in boxes 3, 4, and 5 (Wilcoxon rank sum test, $p<0.05$; Fig. 8). River flow explained $72 \%$ of interannual variation in annual mean surface net $\mathrm{O}_{2}$ production in the upper estuary $(p<0.01)$ but only $15 \%(p<0.1)$ and $36 \%(p<$ 0.01 ) in the middle and lower estuary, respectively (Testa 2006). Bottom-layer $\mathrm{O}_{2}$ consumption was significantly higher in box 5 after 1990 but significantly lower in the upper estuary (box 2) after 1990 (Wilcoxon rank sum test, $p<0.01$; Fig. 8).

\section{Trends and Controls on Hypoxia}

Bottom waters of the Patuxent River estuary develop hypoxia $\left(\mathrm{O}_{2}<62.5 \mu \mathrm{M}\right)$ between May and September. The extent and severity of hypoxia varied among years with no trend over time in response to sewage treatment upgrades (Fig. 9a). The volume of hypoxia in bottom waters was significantly correlated with river flow (Fig. 9b) for annual mean flow $\left(r^{2}=0.35, p<0.01\right)$ and late winter-spring (February to May) flow $\left(r^{2}=0.49, p<0.01\right)$. We found two separate positive correlations between $\mathrm{NO}_{3}{ }^{-}$load at Bowie, $\mathrm{MD}$, USA and hypoxic volume when data were parsed into pre- and post-BNR years, with more hypoxic volume per unit $\mathrm{NO}_{3}{ }^{-}$load after BNR was initiated (after 1990) than before (Fig. 9c).

\section{Discussion}

\section{Regional Differences in Water Quality Responses}

The longitudinal axes of estuarine ecosystems are generally characterized by steep gradients of salinity, water clarity, and nutrient concentrations, as well as associated biological structure. Consequent regional differences in nutrient limitation (Fisher et al. 1992), light limitation (Pennock and Sharp 1994), and ecosystem metabolism (Heath 1995) set the stage for differential responses to eutrophication along an estuarine axis. The proximity of estuarine regions to nutrient sources also affects their response to changes in loading (Mallin et al. 2005), where ecological responses to nutrient loading changes decline with distance from sources. 

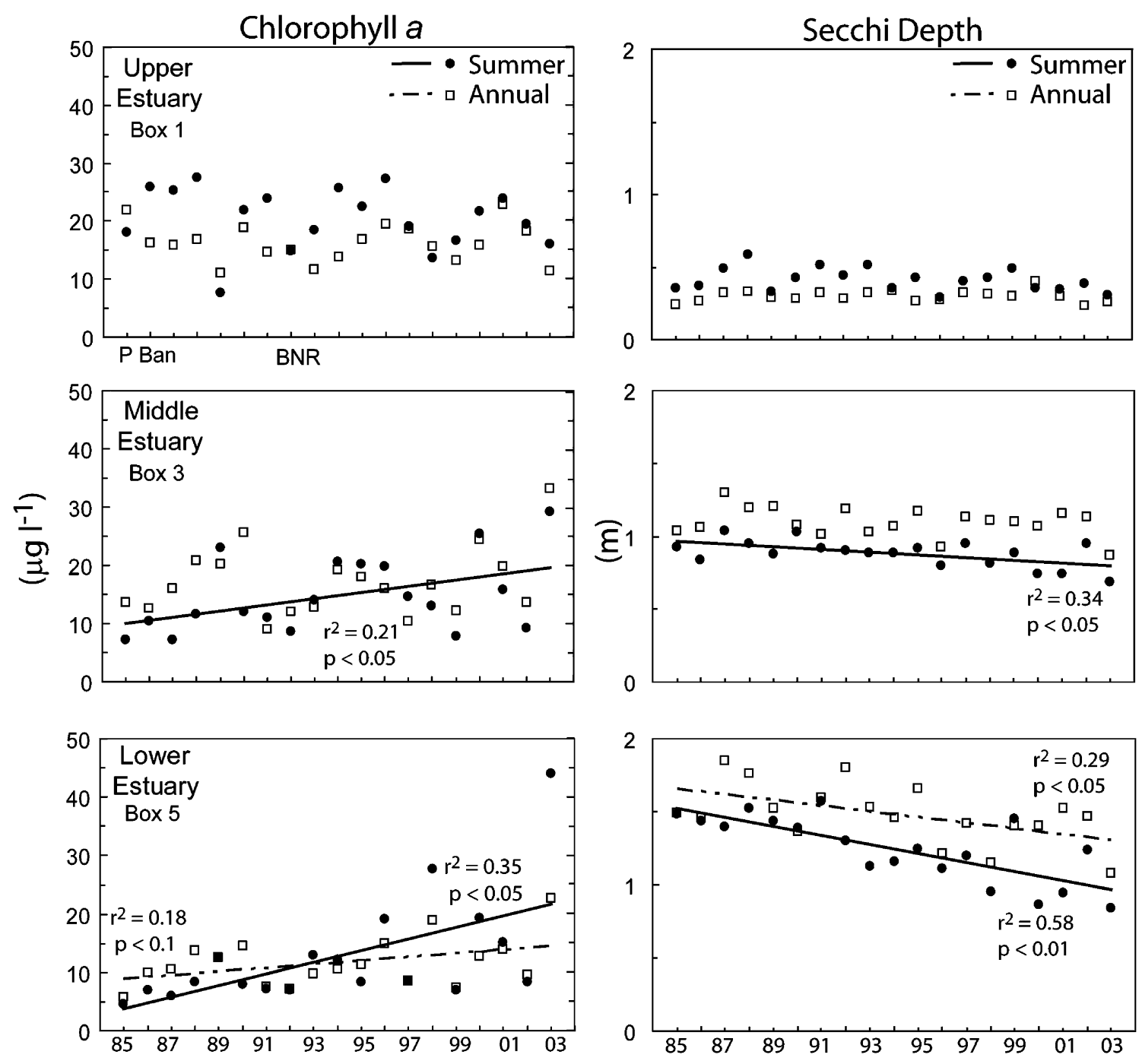

Fig. 7 Time series (1985 to 2003) of annual mean (open squares) and summer (May to August) mean (closed circles) chl-a (left panel) and Secchi depth (right panel) in surface waters of the upper (box 1), middle (box 3), and lower (box 5) Patuxent River estuary. Trend lines

In the upper Patuxent region (tidal fresh and oligohaline), declines in DIN and DIP concentrations and phytoplankton biomass and productivity reflect the effects of sewage treatment upgrades (Paerl et al. 2004). The fact that declines in planktonic chl- $a$ were nonsignificant, despite statistically lower nutrient levels, suggests that phytoplankton growth was predominantly light-limited (Pennock and Sharp 1994) in this region due to high turbidity (Testa 2006). Increased coverage of submerged aquatic plants in shallow flats of the upper Patuxent following BNR suggests a causal linkage between nutrient load reduction, decreased algal biomass (primarily epiphytic but also planktonic), and increased light availability for submerged plant growth (Kemp et al. 2004, 2005; Fisher et al. 2006). Reduced chl- $a$ in the upper estuary may also have contributed to decreased $\mathrm{O}_{2}$ consumption in underlying bottom layers (Fig. 8). Similar ecological and water quality responses have been reported for other coastal systems, with managed nutrient load reductions causing significant declines in nutrient concentrations (Smith et al. 1981; Carstensen et al. 2006), as well as increases in water clarity, dissolved $\mathrm{O}_{2}$ (Brosnan and O'Shea 1996; Johansson and Wallstrom 2001; Mallin et al. 2005), and submerged aquatic plants (Lewis et al. 1998; Greening and Janicki 2006) in brackish and saline ecosystems.

Although the Patuxent's middle region experienced significant declines in DIN and DIP concentrations following the implementation of BNR, stable or increasing trends 


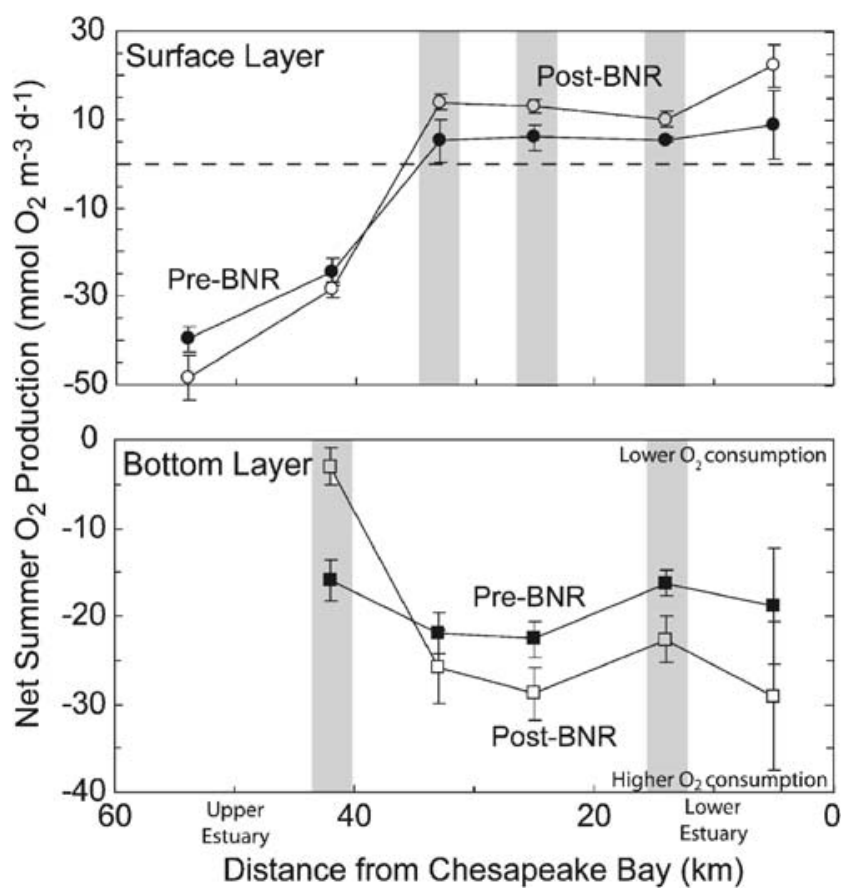

Fig. 8 Mean rates of summer (May to August) box-model-computed net $\mathrm{O}_{2}$ production $( \pm \mathrm{SE})$ in surface layers (top panel) and bottom layers (bottom panel) along the estuarine axis of the Patuxent River estuary in the years before BNR (1985-1990; closed circles and squares) and the years after BNR (1991-2003; open circles and squares). Shaded regions indicate where pre- and post-BNR means are significantly different (Wilcoxon rank sum tests, $p<0.05$ )

were observed for chl- $a$ and turbidity for both annual and summer mean values. These trends suggest that reductions in point-source nutrient inputs alone were insufficient to improve these key water quality properties in this region. These results raise questions about trends in nutrient inputs from other sources, including direct inputs from local nonpoint sources. We focused on DIN because $\mathrm{N}$ has been shown to be the most limiting nutrient for phytoplankton growth in the middle and lower regions of the Patuxent (D'Elia et al. 1986; Fisher et al. 1992). Model-computed, nonpoint inputs of TN from the adjacent watershed directly to the middle estuary suggest a slight increase in $\mathrm{N}$ load from 1985 to 1997 . These nonpoint loads were twice the point-source loads after 1990, indicating that reductions in $\mathrm{N}$ inputs from sewage effluents may have been largely replaced by increases in nonpoint $\mathrm{N}$ loading during recent years (Rask et al. 1999). In fact, annual mean surface-layer net $\mathrm{O}_{2}$ production rates (Fig. 11) and summer (May to August $)$ chl- $a$ concentrations $\left(r^{2}=0.38, p<0.01\right)$ both correlate with variations in the total $\mathrm{TN}$ loads from point and nonpoint sources (1985 to 1997) in the middle estuary. In part, this trend of increasing nonpoint $\mathrm{N}$ load may be associated with above-average river flow in a 5-year period following BNR (1993 to 1997). However, chl- $a$, net $\mathrm{O}_{2}$ production, and turbidity were higher per unit river flow during the years after 1998 than during all years before (Testa 2006), indicating other factors causing continued poor water quality in the middle estuary.

Alternative nutrient sources to fuel sustained phytoplankton biomass and productivity in the middle estuary include direct atmospheric deposition and transport from the upper Patuxent. Trends in DIN loads from precipitation have, however, remained statistically unchanged since the 1980s (NADP 2005). Although increased freshwater flow can cause elevated phytoplankton growth in many estuarine
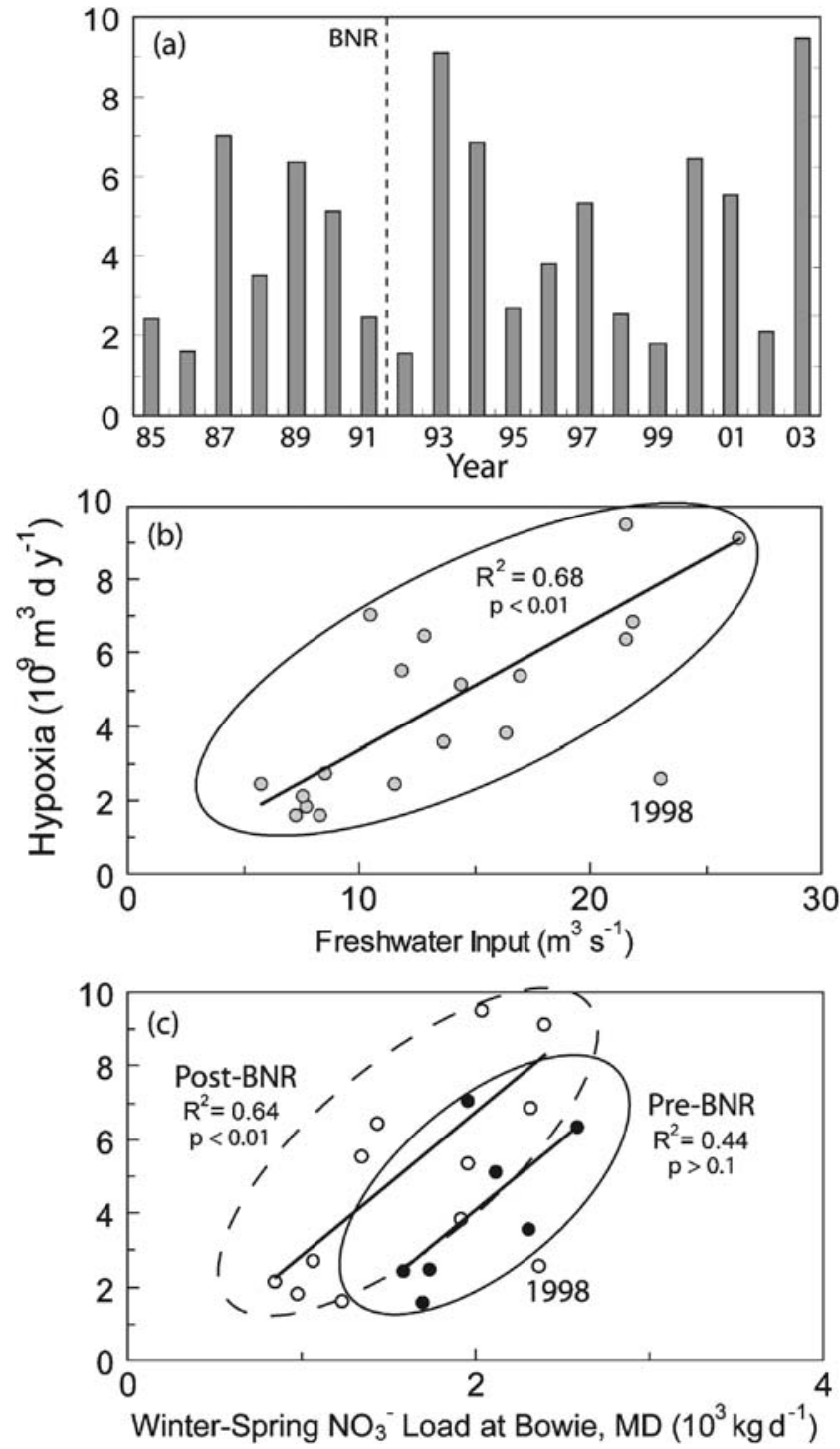

Fig. 9 a Time series (1985 to 2003) of hypoxia quantified as hypoxic volume days in the Patuxent River estuary. HVD is the annual integral under the time series of volume in the estuary with $\mathrm{O}_{2}<62.5 \mu \mathrm{M}$. The vertical dashed line indicates the initiation of BNR. b Relationship between HVD and winter-spring river flow (February to May), with outlier year (1998) not included in regression. c Correlations between HVD and $\mathrm{NO}_{3}{ }^{-}$in years before BNR (filled circles) and after BNR (open circles) with 1998 not included in regressions 
regions (e.g., Boynton and Kemp 2000; Paerl et al. 2006), including the Patuxent (Testa 2006), there was no trend in annual river flow from 1985 to 2003 . Trends in box-modelcomputed DIN transport rates from the upper to middle estuary were negative (but insignificant) from 1985 to 2003, possibly reflecting the effects of sewage treatment upgrades. Considering that both high flow and reduced DIN uptake by lower chl- $a$ concentrations (e.g., Paerl et al. 2004) in the upper estuary after 1990 did not lead to elevated seaward DIN transport over this period, the explanation for recent (1998 to 2003) poor water quality in this region remains unresolved.

The lower estuary also experienced significant increases in chl- $a$, net $\mathrm{O}_{2}$ production, and turbidity levels after 1990 (especially during summer), despite decreasing DIN concentrations. Because of the relatively small area of watershed draining directly into the lower estuary, as well as the reduced post-BNR advection of DIN from upstream, $\mathrm{N}$ inputs from watershed sources are likely not responsible for the declining trends in the water quality of this region. The lower estuary is, however, connected to the main stem of Chesapeake Bay, which is a large nutrient-enriched system (Kemp et al. 2005). Box-model computations of net exchange of DIN between the Patuxent and Chesapeake Bay revealed an erratic but significantly upward trend in net DIN flux from the Bay to the Patuxent since 1985 (Fig. 10). Although there was a trend of increasing net influx of total dissolved nitrogen, DIN was the dominant (70\%) form of $\mathrm{N}$. Most of the DIN entering the Patuxent from the bay tends to be delivered from May to July (Fisher et al. 2006), the period of the largest increases in chl- $a$ and net $\mathrm{O}_{2}$ production. In fact, net DIN inputs from Chesapeake Bay were significantly correlated with both annual mean net $\mathrm{O}_{2}$ production $\left(r^{2}=0.53, p<0.01\right.$, Fig. 11) and summer mean chl- $a\left(r^{2}=0.50, p<0.01\right.$, regression not shown), suggesting that DIN exchange with Chesapeake Bay fueled net organic production in this region (Fig. 11). Similarly, nutrient inputs from enriched seaward waters have been linked to water quality dynamics in other tributaries of Chesapeake Bay (Jordan et al. 1991), as well as other coastal systems (e.g., de Jonge 1997).

\section{Assessing Patuxent-Chesapeake Bay interactions}

While box-model-computed seaward DIN transport from the middle to the lower estuary declined by $\sim 1.010^{3} \mathrm{~kg} \mathrm{~N}$ per day from 1991 to 2003, net DIN inputs from Chesapeake Bay increased by a comparable rate, effectively replacing the managed reduction in watershed DIN input to this estuarine region (Fig. 10). DIN derived from Chesapeake Bay enters the Patuxent in the bottom layer and is subsequently transported to surface waters via vertical upwelling and diffusive exchange to support plankton
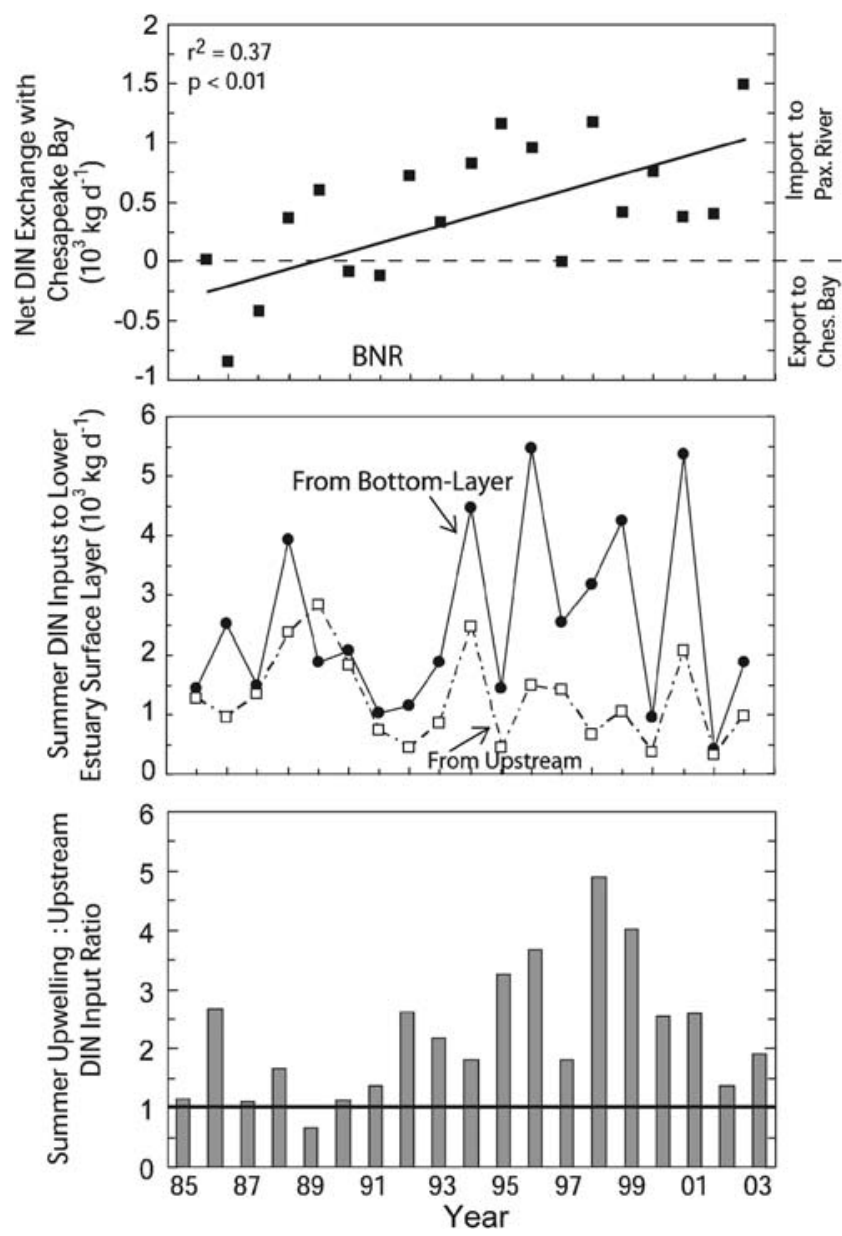

Fig. 10 Time series (1985 to 2003) of box-model-computed annual mean net exchange of DIN between the Patuxent River estuary and main stem Chesapeake Bay (top panel, positive values indicate net input into the Patuxent River estuary), summer mean (May to August) inputs of DIN (computed by the box model) to the surface layer of the lower estuary from upstream waters and from underlying bottom waters (middle panel), and the ratio of summer mean vertical DIN inputs to horizontal DIN inputs from upstream to the surface layer of box 5 (bottom panel, solid black line indicates a ratio of one, where horizontal inputs are equal to vertical inputs)

production. This vertical DIN transport was the dominant source of DIN to the lower estuary's surface layer after 1990, both annually and during summer (Fig. 10), and vertical inputs were sufficient to support $80-100 \%$ of boxmodel-computed surface-layer net $\mathrm{O}_{2}$ production rates.

We explored key factors that could have contributed to the observed temporal trend of increasing net input of DIN from Chesapeake Bay to the Patuxent. Two mechanisms were considered: (1) increased net advection of water derived from a strengthening of the two-layer gravitational circulation and/or (2) an increased gradient of DIN concentration from the bay to the Patuxent. Box-model calculations indicate that the first mechanism can be ruled out because there was no significant trend in advective 


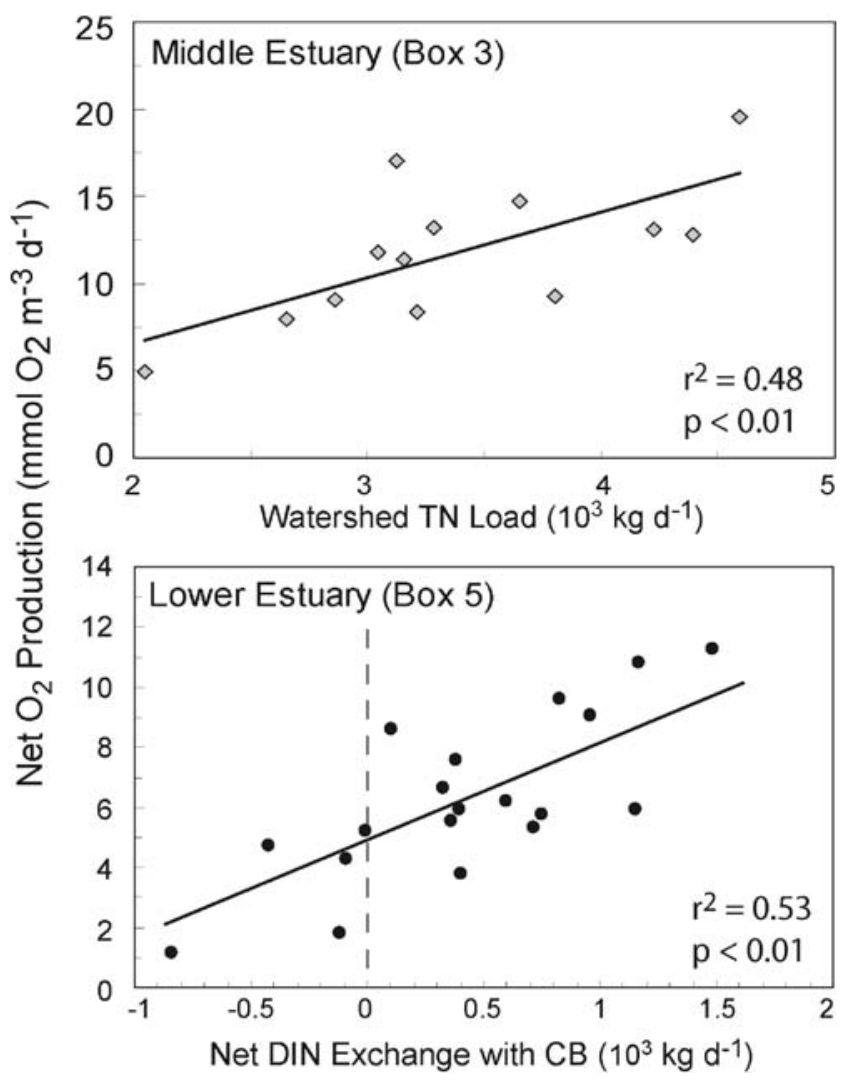

Fig. 11 Regression of total nitrogen load (nonpoint + septic + point loads) from above Benedict Bridge with net $\mathrm{O}_{2}$ production in the surface layer of box 3 (middle estuary). Total nitrogen loads for the region above Benedict Bridge are output from the Chesapeake Bay Watershed Model for the Patuxent River. Data include the years 1985 to 1997 and are annual means. Regression of annual mean net DIN exchange between the Patuxent River estuary and main stem Chesapeake Bay with annual mean net $\mathrm{O}_{2}$ production in the surface layer of box 5 (lower estuary)

water transport from the bay to the Patuxent during this time period. The second explanation appears to be more likely. The normalized difference (ND) in DIN concentration between the Bay and the Patuxent $\left(\mathrm{ND}=\left(\mathrm{DIN}_{\mathrm{BAY}}-\right.\right.$ $\left.\left.\mathrm{DIN}_{\mathrm{PAX}}\right) /\left[\left(\mathrm{DIN}_{\mathrm{BAY}}+\mathrm{DIN}_{\mathrm{PAX}}\right) / 2\right]\right)$ increased significantly over time from 1985 to $2003\left(r^{2}=0.41, p<0.01\right.$, +0.01 year $^{-1}$ ) and net DIN input from Chesapeake Bay was significantly correlated with this gradient from 1990 through $2003\left(r^{2}=0.52, p<0.05\right)$. Thus, the modeled net input of DIN from Chesapeake Bay appears to have been driven largely by a relative decline in Patuxent DIN concentrations following the upgrade of nutrient management in the Patuxent watershed. Further research is needed to identify specific mechanisms underlying this trend in the Patuxent and how similar effects could occur in other estuaries. Simulation modeling studies could be used to test hypotheses about alternative mechanisms (Lung and Nice 2007), including the effects of variations in Susquehanna flow, climate-induced shifts in estuarine circulation, and changes in Chesapeake Bay's lateral seiching events (e.g., Malone et al. 1986).

The observed long-term increases in both DIN import from Chesapeake Bay and chl- $a$ in the lower Patuxent estuary raise additional questions. Specifically, how can increased DIN inputs be reconciled with lower DIN concentrations and how can lower DIN concentrations be reconciled with increasing chl- $a$ ? The explanation may lie in correctly assigning primary causation inferred from correlations. As explained above, it appears that the decrease in DIN concentration in the Patuxent (and resultant increased DIN gradient between the Patuxent and Bay) was most responsible for inducing an increase in net import of DIN from the bay. The inverse causal relationship (i.e., increased DIN input caused decreased DIN concentration) is illogical. Similarly, it is highly unlikely, if not impossible, that decreasing DIN concentrations caused increases in phytoplankton production and chl- $a$. The inverse is, however, consistent with our observations and conceptual understanding, where increases in phytoplankton production and chl- $a$ (as well as PON) could have contributed to the decrease in DIN concentrations that led to the DIN import. This bay-derived DIN may have contributed to the summer phytoplankton $\mathrm{N}$ requirements. We propose that these patterns were likely initiated by a change in grazing on summer phytoplankton (i.e., a topdown effect), although the possibility remains that other unidentified and unmeasured factors were involved in these dynamics.

\section{Role of Top-down Control on Phytoplankton}

Recent work in the Patuxent and other regions of Chesapeake Bay has suggested that the abundance of a planktivorous ctenophore (M. leidyi) has generally increased during the last two decades, and this increase has been linked to declines in one of its predators, Chrysaora quinquecirrha (Purcell and Decker 2005; Breitburg and Fulford 2006). We hypothesized that increased ctenophore grazing on copepods could have caused a top-down cascade that favors elevated phytoplankton biomass (Deason and Smayda 1982). Analyses of monitoring data from the middle region of the Patuxent estuary (boxes 3 and 4) revealed a fivefold increase in summer (June-August) abundance and biovolume of M. leidyi since 1994 and a concomitant fourfold decline in the abundance of the herbivorous copepod, A. tonsa (Fig. 12; CBP 2005). We estimated that $A$. tonsa filtration declined from $15-20 \%$ of the water column per day prior to 1995 to $<1 \%$ between 1997 and 2002 (using maximal clearance rates of $23 \mathrm{ml}$ per copepod per day, Reaugh et al. 2007). Such a decline in copepod grazing could readily cause a substantial change in summer algal biomass (Sellner and Kachur 1987; White and Roman 

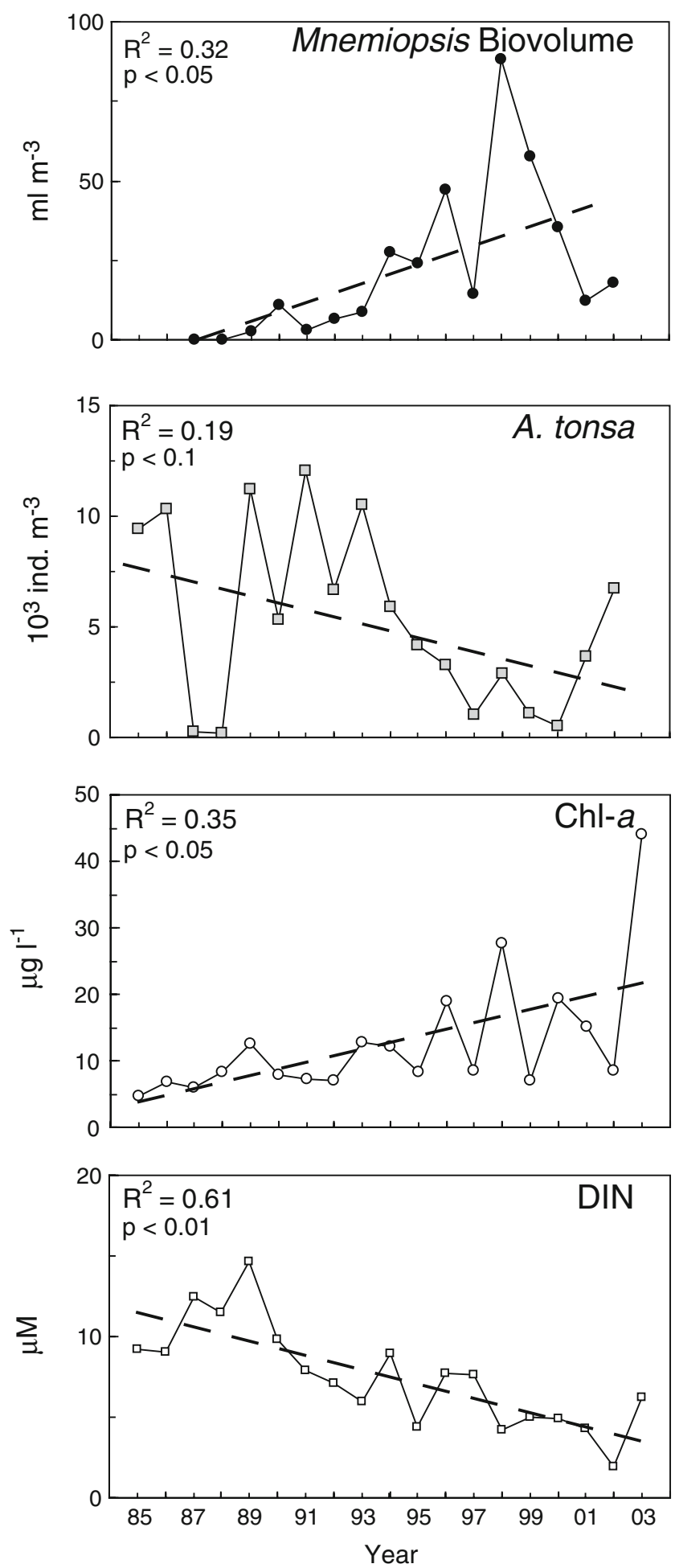

Fig. 12 Time series (1985 to 2003) of summer mean (June to August) M. leidyi biovolume (top panel) and adult A. tonsa concentration (second from top panel) from a station in the mesohaline Patuxent River estuary (Chesapeake Bay Monitoring Station LE1.1) and summer mean (June to August) chl-a (second from bottom panel) and DIN concentration (bottom panel) in the lower Patuxent estuary (box 5)
1992). Although copepods also prey on microzooplankton in summer (White and Roman 1992; Reaugh et al. 2007), relatively large edible phytoplankton (e.g., Thalassiosira sp., Cyclotella sp.) also tends to be abundant in this region in summer (CBP 2005). Although it is not possible to establish causality using retrospective analysis of monitoring data, this evidence suggests that top-down trophic interactions played a key role in observed water quality trends.

\section{Temporal Trends in Hypoxic Volume}

One of the goals of sewage treatment upgrades in the Patuxent watershed was to alleviate low summer bottomwater $\mathrm{O}_{2}$ concentrations and associated physiological stress and mortality for many estuarine organisms (e.g., Diaz 2001; Breitburg et al. 2003). This analysis (Fig. 9a) and other recent studies (Fisher et al. 2006) indicate that sewage treatment upgrades have not reduced hypoxia in the Patuxent estuary. This result is not surprising, considering the elevated chl- $a$ and net $\mathrm{O}_{2}$ production in the lower estuary following sewage treatment upgrades and associated high rates of bottom-layer respiration in this region (Testa and Kemp 2008). Because freshwater flow contributes to hypoxia in this estuary (Fig. 9b), via both nutrientenhanced algal production and increased stratification, above-average flow in the mid-1990s helped sustain hypoxia. DIN inputs from Chesapeake Bay also contributed nutrition to elevated rates of organic matter production and resultant bottom-layer $\mathrm{O}_{2}$ consumption in the lower estuary (Figs. 7 and 8), and there was no evidence of increasing organic matter inputs from the Bay. This mechanism is supported by the fact that more hypoxia occurred per unit $\mathrm{NO}_{3}{ }^{-}$loading from the watershed after 1990 than before (Fig. 9c), supporting the conclusion that Chesapeake Bay has become an increasingly important $\mathrm{N}$ source to the lower Patuxent. Thus, to help relieve hypoxia in estuaries like the Patuxent, which are connected to nutrient-rich waters, nutrient inputs need to be managed from both watershed sources and seaward sources.

Implications

This analysis illustrates the utility of long-term water quality monitoring data to provide a basis for empirical analysis and to support box-model computations of net $\mathrm{O}_{2}$ production and nutrient transport rates. Box-model computations of nutrient transport provide an interpretive framework to examine possible causes and mechanisms underlying water quality trends and are thus useful for management-related research. Our results underscore the fact that even complex water quality patterns in variable and open estuaries can be better understood when detailed 
data are available for analysis. Although upgrades of sewage treatment may lead to improved water quality in upstream regions of estuaries like the Patuxent, interactions with adjacent nutrient-rich waters may inhibit water quality improvements in more seaward regions. Nutrient reduction strategies for Chesapeake Bay tributaries, and perhaps other estuaries, should consider the distinction between watershed-driven water quality in landward regions versus Chesapeake-Bay-influenced water quality in seaward waters. It also appears that changes in upper trophic levels may translate down the food web in estuaries and result in measurable effects on phytoplankton biomass and production, emphasizing the need to consider the interacting effects of "top-down" versus "bottom-up" controls on phytoplankton when assessing consequences of nutrient input management. Although eutrophication and productivity have been successfully reduced in many estuaries in response to managed nutrient load reductions (Brosnan and O'Shea 1996; Lewis et al. 1998; Johansson and Wallstrom 2001; Mallin et al. 2005; Greening and Janicki 2006), changing nutrient sources, climatic factors, and food web changes have made the Patuxent's response to management more complex.

Acknowledgements We are indebted to L. Sanford for critical reviews of previous drafts and many helpful suggestions. L. Linker generously provided output data from the Chesapeake Bay Watershed Model. D. Kimmel helped with statistical analyses. Data were kindly provided by the Chesapeake Bay Program and the Maryland Department of Natural Resources. This work was funded by a Horn Point Laboratory Research Fellowship, a NOAA National Estuarine Research Reserve System Graduate Research Fellowship, the National Science Foundation (BES-0618986), and the Department of Commerce, NOAA (NA07NOS4780191). This is contribution No. 4215 of the University of Maryland Center for Environmental Science. The information in this document has been funded in part by the U.S. Environmental Protection Agency. It has been subjected to review by the National Health and Environmental Effects Research Laboratory and approved for publication. Approval does not signify that the contents reflect the views of the Agency, nor does mention of trade names or commercial products constitute endorsement or recommendation for use. This is contribution number 1337 from the Gulf Ecology division.

\section{References}

ACT Patuxent River Buoy Data. 2005. Alliance for coastal technologies. http://hpl.cbos.org/download.php. Accessed 30 February 2005.

Boynton, W.R., and W.M. Kemp. 2000. Influence of river flow and nutrient loads on selected ecosystem processes: a synthesis of Chesapeake Bay data. In Estuarine science, a synthetic approach to research and practice, ed. J.E. Hobbie, 269-298. Washington D.C.: Island Press.

Breitburg, D.L., and R.S. Fulford. 2006. Oyster-sea nettle interdependence and altered control within the Chesapeake Bay ecosystem. Estuaries and Coasts 29:776-784.
Breitburg, D.L., A. Adamack, K.A. Rose, S.E. Kolesar, M.B. Decker, J.E. Purcell, J.E. Keister, and J.H. Cowan Jr. 2003. The pattern and influence of low dissolved oxygen in the Patuxent River, a seasonally hypoxic estuary. Estuaries 26:280-297.

Brosnan, T.M., and M.L. O'Shea. 1996. Long-term improvements in water quality due to sewage abatement in the lower Hudson River. Estuaries 19:890-900. doi:10.2307/1352305.

Caffrey, J.M. 2003. Production, respiration, and net ecosystem metabolism in U.S. estuaries. Environmental Monitoring and Assessment 81:207-219. doi:10.1023/A:1021385226315.

Carpenter, S.R., and J.F. Kitchell. 1988. Consumer control of lake productivity. BioScience 38:764-769. doi:10.2307/1310785.

Carstensen, J., D.J. Conley, J.H. Andersen, and G. Ærtebjerg. 2006. Coastal eutrophication and trend reversal: A Danish case study. Limnology and Oceanography 51:398-408.

CBP Chesapeake Bay Monitoring Program Database. 2005. US Environmental Protection Agency, Chesapeake Bay Program Office. http://www.chesapeakebay.net/. Accessed 15 January 2005.

Cloern, J.E. 2001. Our evolving conceptual model of the coastal eutrophication problem. Marine Ecology Progress Series 210:223-253. doi:10.3354/meps210223.

Cloern, J.E., A.E. Alpine, B.E. Cole, R.L.J. Wong, J.F. Arthur, and M. D. Ball. 1983. River discharge controls phytoplankton dynamics in the northern San Francisco Bay Estuary. Estuarine, Coastal and Shelf Science 16:415-429. doi:10.1016/0272-7714(83) 90103-8.

Cloern, J.E., A.D. Jassby, J.K. Thompson, and K.A. Hieb. 2007. A cold phase of the East Pacific triggers new phytoplankton blooms in San Francisco Bay. Proceedings of the National Academy of Sciences 104:18561-18565. doi:10.1073/pnas.0706151104.

Conley, D.J., S. Markager, J. Andersen, T. Ellermann, and L.M. Svendsen. 2002. Coastal eutrophication and the Danish National Aquatic Monitoring and Assessment Program. Estuaries 25: 848-861.

Deason, E.E., and T.J. Smayda. 1982. Experimental evaluation of herbivory in the ctenophore Mnemiopsis leidyi relevant to ctenophore-zooplankton-phytoplankton interactions in Narragansett Bay, Rhode Island, USA. Journal of Plankton Research 4:219-236. doi:10.1093/plankt/4.2.219.

D'Elia, C.F., J.G. Sanders, and W.R. Boynton. 1986. Nutrient enrichment studies in a coastal plain estuary: Phytoplankton growth in large scale, continuous cultures. Canadian Journal of Fisheries and Aquatic Science 43:397-406.

D'Elia, C.F., W.R. Boynton, and J.G. Sanders. 2003. A watershed perspective on nutrient enrichment, science, and policy in the Patuxent River, Maryland: 1960-2000. Estuaries 26:171-185.

de Jonge, V.N. 1997. High remaining productivity in the Dutch western Wadden Sea despite decreasing nutrient inputs from riverine sources. Marine Pollution Bulletin 34:427-436. doi:10.1016/S0025-326X(96)00143-9.

Diaz, R.J. 2001. Overview of hypoxia around the world. Journal of Environmental Quality 30:275-281.

Duarte, C. 1995. Submerged aquatic vegetation in relation to different nutrient regimes. Ophelia 41:87-112.

Edmondson, W.T. 1970. Phosphorus, nitrogen, and algae in Lake Washington after diversion of sewage. Science 169:690-691. doi:10.1126/science.169.3946.690.

Fisher, T.R., E.R. Peele, J.W. Ammerman, and L.W. Harding Jr. 1992. Nutrient limitation of phytoplankton in Chesapeake Bay. Marine Ecology Progress Series 82:51-63. doi:10.3354/meps 082051.

Fisher, T.R., J.D. Hagy III, W.R. Boynton, and M.R. Williams. 2006. Cultural eutrophication in the Choptank and Patuxent estuaries of Chesapeake Bay. Limnology and Oceanography 51:435-447. 
Gibson, G., R. Carlson, J. Simpson, E. Smeltzer, J. Gerritson, S. Chapra, S. Heiskary, J. Jones, and R. Kennedy. 2000. Nutrient criteria technical guidance manual, lakes and reservoirs. Washington, D.C.: United States Environmental Protection Agency.

Greening, H., and A. Janicki. 2006. Toward reversal of eutrophic conditions in a subtropical estuary: Water quality and seagrass response to nitrogen loading reductions in Tampa Bay, Florida, USA. Environmental Management 38:163-178. doi:10.1007/ s00267-005-0079-4.

Hagy, J.D. 1996. Residence times and net ecosystem processes in the Patuxent River estuary. M.S. Thesis, University of Maryland at College Park, College Park, Maryland.

Hagy, J.D., L.P. Sanford, and W.R. Boynton. 2000. Estimation of net physical transport and hydraulic residence times for a coastal plain estuary using box models. Estuaries 23:328-340. doi:10.2307/1353325.

Heath, M. 1995. An holistic analysis of the coupling between physical and biological processes in the coastal zone. Ophelia 42:95-125.

Howarth, R.W., D.P. Swaney, T.J. Butler, and R. Marino. 2000. Climatic control on eutrophication of the Hudson River estuary. Ecosystems 3:210-215. doi:10.1007/s100210000020.

Jeppesen, E., M. Søndergaard, J.P. Jensen, K. Havens, O. Anneville, L. Carvalho, M.F. Coveney, R. Deneke, M. Dokulil, B. Foy, D. Gerdeaux, S.E. Hampton, K. Kangur, J. Köhler, S. Körner, E. Lammens, T.L. Lauridsen, M. Manca, R. Miracle, B. Moss, P. Nõges, G. Persson, G. Phillips, R. Portielje, S. Romo, C.L. Schelske, D. Straile, I. Tatrai, E. Willén, and M. Winder. 2005. Lake responses to reduced nutrient loading - an analysis of contemporary long-term data from 35 case studies. Freshwater Biology 50:1747-1771. doi:10.1111/j.1365-2427.2005.01415.x.

Jickells, T. 2005. External inputs as a contributor to eutrophication problems. Journal of Sea Research 54:58-69. doi:10.1016/j. seares.2005.02.006.

Johansson, L., and K. Wallstrom. 2001. Urban impact in the history of water quality in the Stockholm Archipelago. Ambio 30:277-281. doi:10.1639/0044-7447(2001)030[0277:UIITHO]2.0.CO;2.

Jordan, T.E., D.L. Correll, J. Miklas, and D.E. Weller. 1991. Longterm trends in estuarine nutrients and chlorophyll, and short-term effects of variation in watershed discharge. Marine Ecology Progress Series 75:121-132.

Kemp, W.M., R. Batiuk, R. Bartleson, P. Bergstrom, V. Carter, C.L. Gallegos, W. Hunley, L. Karrh, E.W. Koch, J.M. Landwehr, K.A. Moore, L. Murray, M. Naylor, N.B. Rybicki, J.C. Stevenson, and D.J. Wilcox. 2004. Habitat requirements for submerged aquatic vegetation in Chesapeake Bay: Water quality, light regime, and physical-chemical factors. Estuaries 27:363-377.

Kemp, W.M., W.R. Boynton, J.E. Adolf, D.F. Boesch, W.C. Boicourt, G. Brush, J.C. Cornwell, T.R. Fisher, P.M. Glibert, J.D. Hagy, L.W. Harding, E.D. Houde, D.G. Kimmel, W.D. Miller, R.I.E. Newell, M.R. Roman, E.M. Smith, and J.C. Stevenson. 2005. Eutrophication of Chesapeake Bay: Historical trends and ecological interactions. Marine Ecology Progress Series 303:1-29. doi:10.3354/meps303001.

Langland, M.J., J.P. Raffensperger, D.L. Moyer, J.M. Landwehr, and G.E. Schwarz. 2006. Changes in streamflow and water quality in selected nontidal basins in the Chesapeake Bay Watershed, 1985-2004: U.S. Geological Survey Scientific Investigations Report 2006-5178, 75 pp, plus appendixes (on $\mathrm{CD}$ ).

Lewis, R.R. Jr., P.A. Clark, W.K. Fehring, H.S. Greening, R.O. Johansson, and R.T. Paul. 1998. The rehabilitation of the Tampa Bay Estuary, Florida, USA, as an example of successful integrated coastal management. Marine Pollution Bulletin 37:468-473. doi:10.1016/S0025-326X(99)00139-3.
Linker, L.C., C.W. Stigall, C.H. Chang, and A.S. Doingian Jr. 1996. Aquatic accounting: Chesapeake Bay watershed model quantifies nutrient loads. Water Environment and Technology 8:48-52.

Linker, L., G. Shenk, R. Dennis, and J. Sweeney. 2000. Cross-media models of the Chesapeake Bay watershed and airshed. Water Quality and Ecosystem Modeling 1:91-122. doi:10.1023/ A:1013934632305.

Lung, W., and S. Bai. 2003. A water quality model for the Patuxent estuary: Current conditions and predictions under changing landuse scenarios. Estuaries 26:267-279.

Lung, W., and A.J. Nice. 2007. Eutrophication model for the Patuxent estuary: Advances in predictive capabilities. Journal of Environmental Engineering 133:917-930. doi:10.1061/(ASCE)07339372(2007)133:9(917).

Mallin, M.A., M.R. McIver, H.A. Wells, D.C. Parsons, and V.L. Johnson. 2005. Reversal of eutrophication following sewage treatment upgrades in the New River estuary, North Carolina. Estuaries 28:750-760.

Malone, T.C., W.M. Kemp, H.W. Ducklow, W.R. Boynton, J.H. Tuttle, and R.B. Jonas. 1986. Lateral variation in the production and fate of phytoplankton in a partially stratified estuary. Marine Ecology Progress Series 32:149-160. doi:10.3354/ meps032149.

Marino, R., and R.W. Howarth. 1993. Atmospheric oxygen exchange in the Hudson River: Dome measurements and comparison with other natural waters. Estuaries 16:433-445. doi:10.2307/ 1352591.

McClelland, J.W., and I. Valiela. 1998. Changes in food web structure under the influence of increased anthropogenic nitrogen inputs to estuaries. Marine Ecology Progress Series 168:259-271. doi:10.3354/meps168259.

MD DNR Shallow Water Monitoring Program Database. 2005. Maryland Department of Natural Resources. http://www.eye sonthebay.net. Accessed 18 March 2005.

Millard, S.P. 2002. Environmental stats for S-Plus user's manual version 2.0, 2nd Edition. New York: Springer.

NADP National Atmospheric Monitoring Database. 2005. National Atmospheric Deposition Program. http://nadp.sws.uiuc.edu/sites/ siteinfo.asp?net=NTN\&id=MD13. Accessed 17 October 2005.

NOAA Annual Climate Summaries. 2005. U.S. National Oceanographic and Atmospheric Administration. http://www7.ncdc. noaa.gov/IPS. Accessed 20 February 2005.

Officer, C.B. 1980. Box models revisited. In Estuarine and wetland processes, eds. P. Hamilton, and R.B. Macdonald, 65-114. New York:Plenum.

Paerl, H.W. 1988. Nuisance phytoplankton blooms in coastal, estuarine, and inland waters. Limnology and Oceanography 33:823-847.

Paerl, H.W., L.M. Valdes, A.R. Joyner, M.F. Piehler, and M.E. Lebo. 2004. Solving problems resulting from solutions: Evolution of a dual nutrient management strategy for the eutrophying Neuse River Estuary, North Carolina. Environmental Science and Technology 38:3068-3073. doi:10.1021/es0352350.

Paerl, H.W., L.M. Valdes, B.L. Peierls, J.E. Adolf, and L.W. Harding Jr. 2006. Anthropogenic and climatic influences on the eutrophication of large estuarine systems. Limnology and Oceanography $51: 448-462$

Pennock, J.R., and J.H. Sharp. 1994. Temporal alternation between light- and nutrient-limitation of phytoplankton production in a coastal plain estuary. Marine Ecology Progress Series 111:275288. doi:10.3354/meps111275.

Purcell, J.E., and M.B. Decker. 2005. Effects of climate on relative predation by scyphomedusae and ctenophores on copepods in Chesapeake Bay during 1987-2000. Limnology and Oceanography 50:376-387. 
Rask, N., S.E. Pedersen, and M.H. Jensen. 1999. Response to lowered nutrient discharges in the coastal waters around the island of Funen, Denmark. Hydrobiologia 393:69-81. doi:10.1023/ A:1003510405699.

Reaugh, M.L., M.R. Roman, and D.K. Stoecker. 2007. Changes in plankton community structure and function in response to variable freshwater flow in two tributaries of the Chesapeake Bay. Estuaries and Coasts 30:403-417.

Schindler, D.W. 1978. Factors regulating phytoplankton production and standing crop in the world's freshwaters. Limnology and Oceanography 23:478-486.

Sellner, K.G., and M.E. Kachur. 1987. Relationships between phytoplankton, nutrients, oxygen flux and secondary producers. In Lecture notes on coastal and estuarine studies, 23:Ecological Studies in the Middle Reach of Chesapeake Bay, Calvert Cliffs, ed. K.L. Heck, 12-36. Berlin: Springer.

Smith, S.V., W.J. Kimmerer, E.A. Laws, R.E. Brock, and T.W. Walsh. 1981. Kaneohe Bay sewage diversion experiment: Perspectives on ecosystem responses to nutritional perturbation. Pacific Science 35:279-395.
Stankelis, R.M., M.D. Naylor, and W.R. Boynton. 2003. Submerged aquatic vegetation in the mesohaline region of the Patuxent estuary: Past, present, and future status. Estuaries 26: 186-195.

Testa, J.M. 2006. Factors regulating variability in water quality and net biogeochemical fluxes in the Patuxent River estuary. M.S. Thesis, University of Maryland at College Park, College Park, Maryland.

Testa, J.M., and W.M. Kemp. 2008. Variability of biogeochemical processes and physical transport in a partially stratified estuary: A box-modeling analysis. Marine Ecology Progress Series 356:63-79. doi:10.3354/meps07264.

USGS Surface Water Data. 2005. US Geological Survey. http://va. water.usgs.gov/chesbay/RIMP/adaps2/pat.adaps.dat. Accessed 20 February 2005.

White, J.R., and M.R. Roman. 1992. Seasonal study of grazing by metazoan zooplankton in the mesohaline Chesapeake Bay. Marine Ecology Progress Series 86:251-261. doi:10.3354/ meps086251. 